\title{
Article \\ The Potential of Tram Networks in the Revitalization of the Warsaw Landscape
}

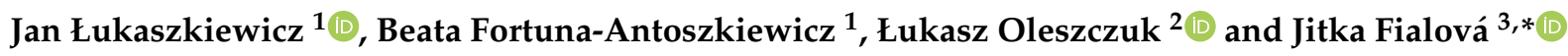 \\ 1 Department of Landscape Architecture, Institute of Environmental Engineering, Warsaw University of Life \\ Sciences-SGGW, UL. Nowoursynowska 159, 02-776 Warszaw, Poland; jan_lukaszkiewicz@sggw.edu.pl (J.Ł.); \\ beata_fortuna_antoszkiewicz@sggw.edu.pl (B.F.-A.) \\ 2 Legal and Analytical Services Department, 02-776 Warsaw, Poland; oleszczuk@zupa.org.pl \\ 3 Department of Landscape Management, Faculty of Forestry and Wood Technology, Mendel University in \\ Brno, 61300 Brno, Czech Republic \\ * Correspondence: Jitka.fialova@mendelu.cz; Tel.: +420-545134096
}

check for updates

Citation: Łukaszkiewicz, J.; Fortuna-Antoszkiewicz, B.; Oleszczuk, Ł.; Fialová, J. The Potential of Tram Networks in the Revitalization of the Warsaw Landscape. Land 2021, 10, 375. https://doi.org/10.3390/ land 10040375

Academic Editors: Alessio Russo and Giuseppe T. Cirella

Received: 26 February 2021

Accepted: 1 April 2021

Published: 4 April 2021

Publisher's Note: MDPI stays neutra with regard to jurisdictional claims in published maps and institutional affiliations.

Copyright: (c) 2021 by the authors. Licensee MDPI, Basel, Switzerland. This article is an open access article distributed under the terms and conditions of the Creative Commons Attribution (CC BY) license (https:/ / creativecommons.org/licenses/by/ $4.0 /)$.

\begin{abstract}
The current crisis of worldwide agglomeration and economic, spatial, and ownership factors, among others, mean that there is usually a shortage of new green areas, which are socially very beneficial. Therefore, various brownfields or degraded lands along public transport routes, e.g., tram lanes, are effectively transformed for this purpose. The significant potential of tram systems is that they can became a backbone of green corridors across the city. This case study of the Warsaw tram system (total length over $300 \mathrm{~km}$ of single tracks in service in 2019) enables us to simulate the potential growth of a biologically active area connected with an increasing share of greenery around tram lanes in Warsaw. Experience allows the authors to present the types of greenery systems based on existing and future tram corridors best suited for this city. The suggested usage of tram lanes as green corridors is in line with the generally-accepted concept of urban green infrastructure. Therefore, the aim of the authors is to present in a condensed fashion their views on a very important issue within the program of the revitalization of the Warsaw landscape by converting where possible the existing tram lines, as well as planning new ones according to the "green point of view".
\end{abstract}

Keywords: cityscape visual perception; green infrastructure; linear parks; sustainable landscape planning; tram lanes; Warsaw

\section{Introduction}

Warsaw, Poland's capital, has a unique character as it was almost totally destroyed during the German occupation (the World War II period). Reconstruction of its infrastructure took decades and still is not complete. In addition, progression of the town's growth could not be based on the development of the existing structure, including the transportation system. The authors strongly believe that the growing demand for moving masses of people around the city is best fulfilled by the modernization and construction of the tram lines.

In the last few decades, there has been a fundamental change in the concept of designing tramway networks all over the world [1-5]. Concerning trams, passenger and environmentally friendly solutions are introduced by increasing accessibility, improving travel efficiency, and reducing energy consumption, thus reducing environmental costs [1-8]. The use of the multi-factor analysis method at each level of tram route planning and extensive promotional and information campaigns cause tramways to receive more and more social attention, as does the involvement of future passengers in the open debate at the design analysis stage (e.g., [5,7-11]). In this context, it is no exaggeration to say that the tramway as a form of public transport becomes a stimulus for developing and revitalizing cities [4,12]. Despite the multitude of solutions used in different countries, there are some similarities between them. One worth noting is the adaptation of degraded, 
fragmented, and marginalized space around buildings and elements of technical infrastructure within tram routes, and incorporating them again into the urban composition $[1,2,4,5]$. By introducing linear green systems accompanying tram lanes (insulating, ecological, and decorative functions) and new publicly accessible places for recreation and relaxation, a new quality in urban planning is achieved, which is also particularly important for the social quality during the COVID-19 pandemic [13-16].

The crisis of urban and industrial agglomerations observed worldwide at the turn of the 21st century manifested itself in several severe dysfunctions. Therefore, in the 21st century, there is a growing need to transform cities towards restoring the urban landscape's harmony and improving the inhabitants' living conditions. Among others, a skillful transformation with a humanistic approach to the entire complex cultural and natural structure of the urban fabric is needed (e.g., [17-22]). Phenomena such as the intensified global migration of people to cities (ca. 5.0 billion in 2030) [7], rising energy prices, and the degradation of the environment and landscapes-a light-hearted instrumental approach to natural resources [23] —overlap with the already existing various shortcomings of the existing functional and spatial solutions in cities, such as the density of buildings in city centers or the phenomenon of "urban sprawl" [13,14,20,22,24].

One of the ever-present problems is the inadequate development of urban public transport systems, which must continuously be adapted to the arising social needs in terms of quality and efficiency (e.g., [1,4,16,25-27]). It is already estimated that urban transport systems worldwide have such a significant impact on the environment that they are responsible for $20-25 \%$ of global energy consumption, $\mathrm{CO}_{2}$ emissions to the atmosphere, gaseous pollutants (e.g., polycyclic aromatic hydrocarbons-PAHs), and dust (e.g., particulate matter-PM) [27-35]. For these reasons, urban transport based on private cars and diesel buses is gradually becoming a thing of the past $[2,3,6,9]$. The future of urban passenger transport involves four areas that are developing very rapidly: electrification, autonomy, connectivity, and sharing [8].

In line with the concept of "sustainable transport", which is increasingly used all over the world and is part of "smart cities" of the future, the aim is to create a public transport systems with a balanced impact on society, the environment, and climate $[5,36]$. There are attempts to combine specific engineering solutions, such as linear technical infrastructure with vegetation (e.g., green tram routes-Figure 1), aimed at crossing the border between the artificial and the natural in order to improve the quality of life on a social scale $[20,21,37]$. However, this is not a simple task, because it is known that urban mobility has two faces; on the one hand, it creates and stimulates economic growth, and on the other, it can also generate undesirable social, spatial, and environmental effects [3,4].

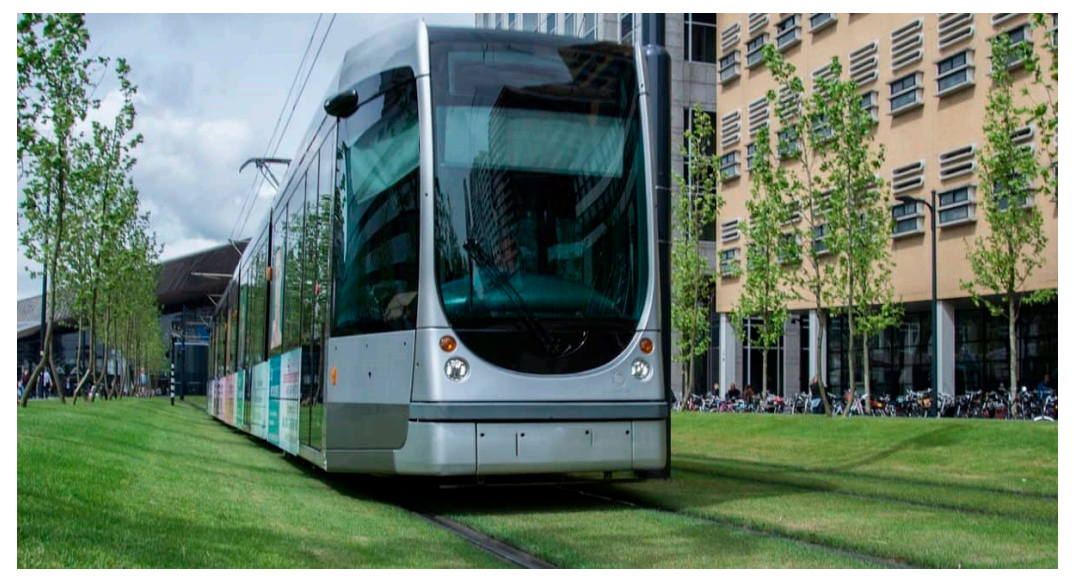

Figure 1. Tram lines as "green corridors" in the urban structure "smart city". Source: Smart City Blog, 29 June 2017 [38]. 
Simultaneously, urban planning formulates hypotheses (which have been confirmed many times in the past) that linear structures of public transport systems may support the revitalization of dysfunctional urban areas. Depending on the adopted priorities, strategies, and local spatial development policy, it is assumed that revitalizing activities will be concentrated along selected linear structures, necessary for the city and with a wide spatial range. It shall help connect the city's internal districts and bind the peripheries closer with the center $[2,4,9,12,39]$. For example, in the last several decades in urban planning in Europe and various regions of the world, a very positive, relatively new, and growing phenomenon has been observed, consisting of strengthening the integration of built-up areas thanks to the presence of tram systems $[1,4,5,39]$.

Therefore, this publication makes a hypothesis that the tram-a necessary and environmentally friendly form of urban public transport-is a crucial urban tool enabling the simultaneous integration of dysfunctional and dispersed parts of the city and-no less important-an essential catalyst for a thorough restructuring of urban green systems and public urban spaces. This applies particularly to Warsaw, where very difficult and complex geological conditions make development of an underground transport system a very costly and time-consuming task.

This publication aims to present the importance and potential of a tram network for the reconstruction and development of the transport infrastructure in Warsaw. At the same time, based on the examples of other European cities that did not have as traumatic a past as Warsaw and that have developed in an evolutionary way, this paper tries to delineate how-drawing on the contemporary canons of sustainable development-the right proportions can be achieved in the design of the urban tram route surroundings, taking into account functional (optimum connection), environmental (resource enrichment), and landscape (the city's image) aspects.

\section{Materials and Methods}

The identification of the issues and the formulation of the main goals of the research allowed us to starting the first stage of work. An extensive literature search was conducted to compile examples of tram systems playing a key role on transformation of urban space. Combinations of keywords including "urban", "city", "tram lanes", "tramways", "revitalization", "green infrastructure", and "linear parks" were used in searching three online literature databases, including Scopus, ISI Web of Knowledge, and Google Scholar.

Issues identified during the literature review were divided synthetically in two major thematic groups:

- city policies (especially in Europe) concerning use of tram systems to stimulate urban development and revitalization of urban spaces;

- the importance of greenery used along tram routes for the urban environment and the quality of life.

The data collected at this stage of the research was from both the literature and the authors' own professional, scientific, and practical experience concerning the design and development of the tramway system in Warsaw. Such an example is the study and development concept of a tram route linking the Gocław and Saska Keppa districts in Warsaw, which consisted of elaboration of different initial variants of spatial solutions, and then open social consultations and elaborations of the final design.

The analysis of collected data allowed us to state that tram systems are an extremely vital tool for the revitalization of urbanized spaces, especially when they are combined with linear green systems (e.g., concerning remediation abilities of plants and the influence of green structures on air filtration in the city). This fact is of great importance not only for urban environments but, what is more crucial, for the urban society and the quality of life.

At the final stage of the work, the data collected from the literature and as part of the authors' own research formed the basis for the actual design work, enabling the development of a theoretical model for the transformation of the city tram system that would fit the specific conditions of Warsaw. 
In general, it is a kind of forecast for the quantitative and qualitative development of a linear greenery layout associated with the city tram system. This form of presentation of the results of the authors' experiments was to show, in a model manner, selected aspects of designing the green forms in the vicinity of tram routes, based on the facts (collected and processed data). Case studies are an adequate and convenient scientific method used successfully in research in the fields of architecture, urban planning, and landscape architecture.

The obtained results in the form of estimated quantitative and qualitative indicators were compared synthetically with the literature in the discussion. On this basis, the final conclusions from the research were formulated.

\section{Results-The Potential of Warsaw's Tram Network}

Tram transport is very common in EU cities. Trams are a key part of EU public transportation, which is responsible for an annual rate of some 50 billion passengers (in 2018) [40]. All the major EU capitals have retained their original tram networks from the 19th century. Some of these networks have been upgraded to light rail standards, called Stadtbahn in Germany, premetros in Belgium, sneltram in the Netherlands, elétrico in Portugal, and fast trams in some other countries. Many city tramway networks extend over municipal boundaries. The city tram has always been efficient and one of the most environmentally-friendly forms of city mass transportation. It is competitive and resourceefficient, and it is typically characterized by low-carbon emissions. As an electric vehicle (EV), unlike other road transport means, it does not emit exhaust gases into the atmosphere, and its durability is many times greater than, for example, a city bus fleet [6]. In terms of the emissions of fine particulate matter (PM 2.5), which poses a great threat to human health and life, a tram is undoubtedly the least harmful compared to a bus (diesel engine) or even an underground $[28,29,31,41]$. Such transport, like low-emission trams, is one of elements of the traffic sector of the Zero Pollution Action Plan draft by the European Commission. The European Green Deal highlights the need for transport to become drastically less polluting in urban areas, emphasizing the importance of a combination of measures aimed at reducing emissions, mitigating urban congestion, and improving public transport options. The tramway as a form of public urban transport seems to be a perfect match for these expectations [16,25-27].

In Poland, tram networks are present in 14 cities. In 2018, the total length of tram lines in the country reached $2338.0 \mathrm{~km}$ (Table 1). Concerning individual Polish provinces (in 2016), the greatest length of tram lines was found in Silesia $(405 \mathrm{~km})$ and the second greatest in Masovia (363 km), of which Warsaw has the greatest share (Figure 2) [42].

Table 1. The total length of tram lines in Poland $(\mathrm{km})$ changing in subsequent years (31 December 2019). Source of data: Statistical Yearbook of the Republic of Poland 2019 [43], compiled by J. Łukaszkiewicz, 2021.

\begin{tabular}{ccccc}
\hline Year & $\mathbf{2 0 1 0}$ & $\mathbf{2 0 1 5}$ & $\mathbf{2 0 1 7}$ & $\mathbf{2 0 1 8}$ \\
\hline $\mathrm{Km}$ & 2254.0 & 2425.0 & 2417.0 & 2338.0 \\
\hline
\end{tabular}




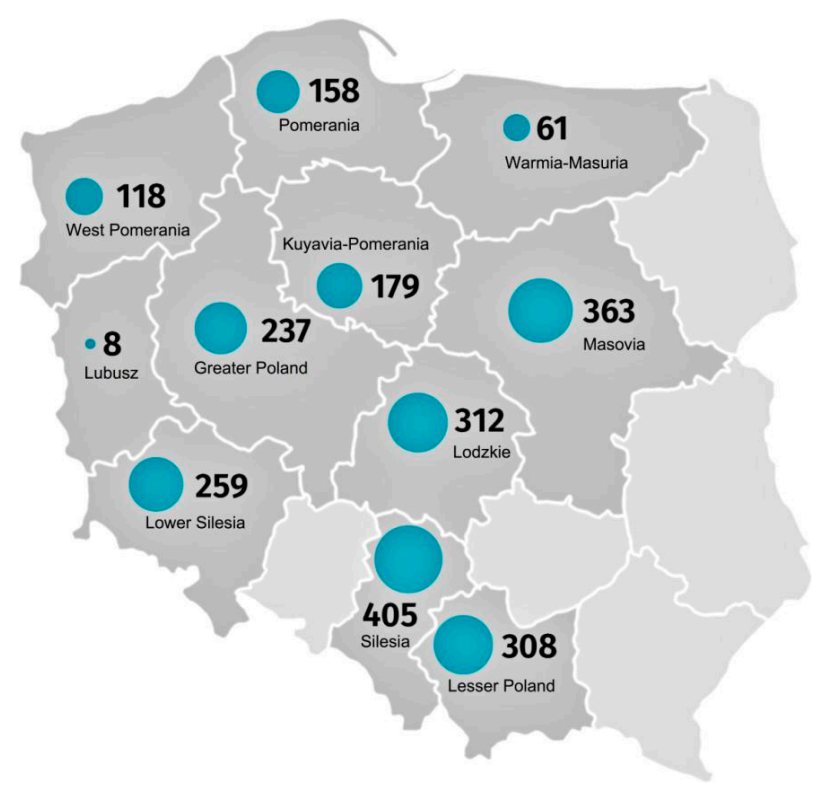

Figure 2. Trams in Poland in 2016-the total length $(\mathrm{km})$ of tram lines in individual provinces (2408 km in total). Source of data: Statistics Poland [43,44], compiled by J. Łukaszkiewicz, 2021.

Concerning the introduction of green tram lanes, the Polish tradition in this matter dates back to the 1930s (Figure 3). Unfortunately, the catastrophic World War II and the following 45 years of communism caused this interesting idea to abandoned for many years, and the first solutions of this type were introduced again only at the end of the 1990s. Fifteen years later, in 2014, green lanes were present in 9 out of 14 Polish cities with tramway transportation systems $[42,45]$. The estimated average balance of the length of green lanes was only $3.6 \%$ then (most in Warsaw $(4.0 \%)$ and Poznań $(4.6 \%)$ ), which accounted for approximately $66.5 \mathrm{~km}$ of the total length of the Polish tram network (ca. $1855.0 \mathrm{~km}$ ) (Figure 4) [46,47].

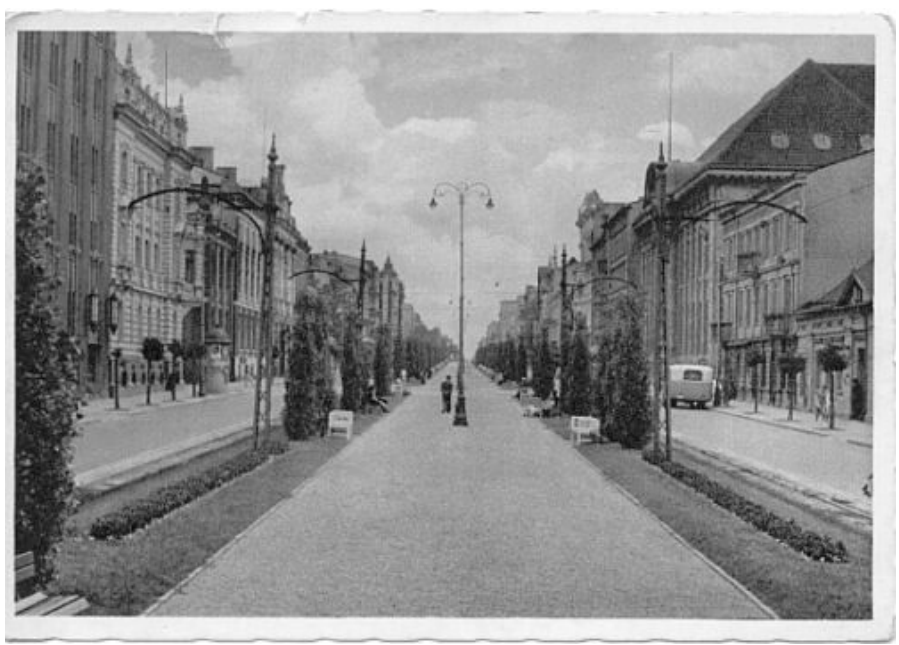

Figure 3. Poland, Łódź, T. Kościuszko Avenue, 1930s/1940s (?)—a tram track in a spectacular floral setting, defining an already existing representative and recreational space (photo: author unknown, private collection).

Regarding Warsaw, introducing vegetation into streets and along tram tracks is not only a recent story. At the end of the 19th century, Warsaw used widespread greening and decorating of the streets with trees, lawns, and ornamental flower beds. Stefan Starzyński, the then distinguished president of Warsaw, transformed the capital into a modern European city under the slogan "Warsaw in flowers and greenery". The widespread introduction 
of vegetation served to raise the overall aesthetics, but it was also a way to improve the living conditions in this extensive and populous city. "...Greenery in the city is a matter of the health of the population. After all, health is the most precious human treasure..." [48] Thus, new parks and squares were established, and trees and vines were planted en masse along the streets together with flower beds and lawns. The lawns were also used for green tram tracks. "...In central districts, where compact buildings made it impossible to establish larger uniform units of greenery, efforts were made to exploit squares, roadways, and streets by establishing a significant number of new green areas and green belts, and by tree-lining several streets and introducing grass into tram tracks..." [49]. These were highly innovative activities, interrupted by the outbreak of World War II.

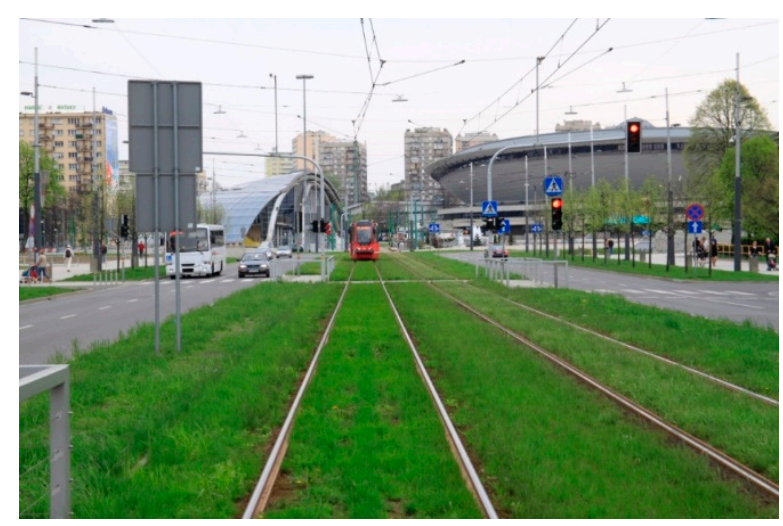

Figure 4. Poland, Katowice, W. Grassy tram lane along Kofranty Avenue. Photo: B. FortunaAntoszkiewicz, IV 2016.

In the second half of the 20th century, while rebuilding the city destroyed by war, efficient public transport was organized, including tram lines, which have been successfully used to this day. Main streets and important new arteries were given a carefully arranged floral settings. The accompanying linear spatial systems were arranged with rows of trees, hedges, and lawns [50,51]. Thanks to this, spatial order was introduced, and insulation and protection zones were consciously shaped, improving the city's climate and increasing street users' safety (Figure 5). Due to technological reasons, the greening of the tracks was abandoned in favor of lawns in parallel strips (Figure 6).
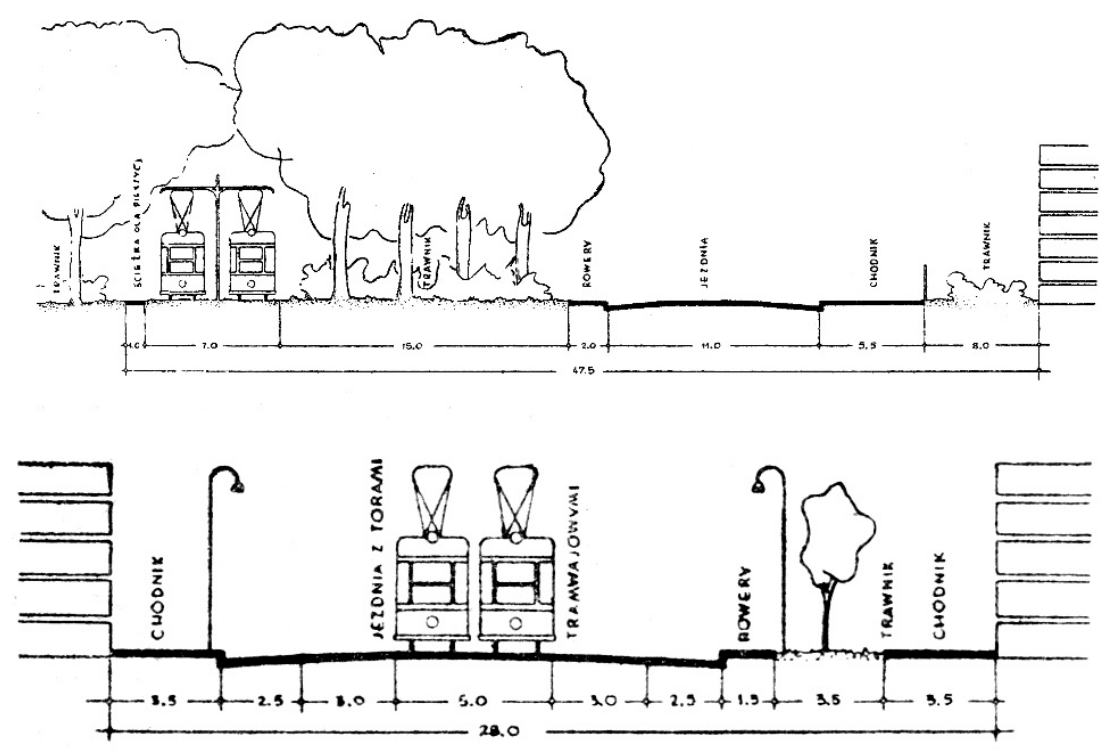

Figure 5. Cross-sections of streets with tram lanes surrounded by trees and greenery-standard from the 1950s [51]. 


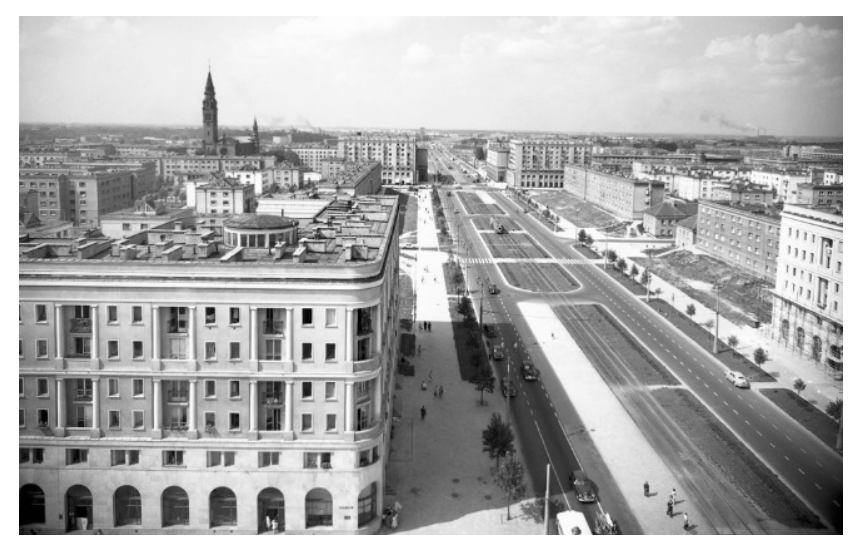

Figure 6. Warsaw, 1950s. The newly arranged J. Marchlewskiego Avenue (currently Jana Pawła II Avenue) - a separate inner lane with a tram line surrounded by greenery (lawns with hedges) and regular rows of young trees on both sides of the road. Photo: Z. Siemaszko, collection: National Digital Archives [52].

Currently in Warsaw, around 70 years later, only fragmentary arrangements remain (dismal remnants !!!) of the old projects. Along with the development of car traffic, parking spaces appeared in place of gradually dying trees and degraded lawns in many cases. Such depletion of natural resources is particularly acute in the city center, where the process of building densification has been progressing over the last decades, often at the expense of small green enclaves (squares, undeveloped areas), and there the green track becomes a solution. Tramlines penetrate the highly urbanized center, making it possible to introduce a collision-free network of linear greenery $[42,46,53,54]$.

At present (data from 2019) the length of green tram lanes in Warsaw has reached $25.0 \mathrm{~km}$ with a total length of approx. $433.0 \mathrm{~km}$ of tracks [46]. When renovating and constructing new tram routes, the Warsaw Trams have started to introduce green lanes as standard, implementing them both on concrete and ballast foundations [47] (Figures 7 and 8).

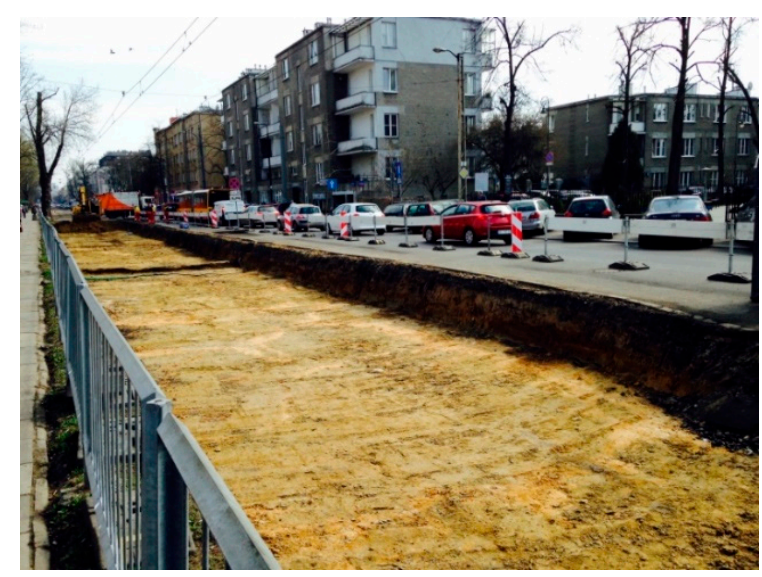

Figure 7. Reconstruction of a tram line, Rakowiecka Street, Warsaw. Photo: J. Łukaszkiewicz, III 2015.

The apparent advantage of green tram lanes today is the reduction of the noise level during the tram operation, the improvement of ecological aspects-increase in biologically effective urban areas-and the improved aesthetic experience of streets in cities [45]. In addition, skillfully-applied greenery allows the sound level from traffic to be reduced by 10.0 to $15.0 \mathrm{~dB}$. This shows how much the sound level of the direct wave emitted by a tram decreases when the side of the tram lane is planted with large deciduous trees. The values of additional attenuation by the green belt range from 0.10 to $0.25 \mathrm{~dB} / \mathrm{m}$, depending on its type and configuration. A series of narrower belts produce more damping than one belt of the same width combined. The first lane, up to $50.0 \mathrm{~m}$ wide, is always the most 
critical. Tree belts with dense shrubs suppress noise by approx. $3.0 \mathrm{~dB}$ for every $30.0 \mathrm{~m}$ of width. Even a band of vegetation with a negligible acoustic attenuation changes the noise spectrum shape by dispersing and absorbing high-frequency components [55-61].

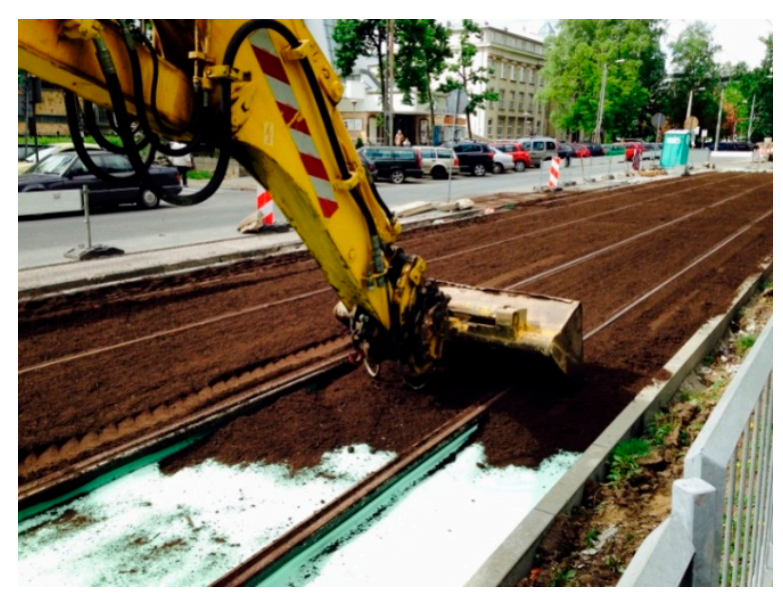

Figure 8. Reconstruction of a tram line-laying a lawn, Rakowiecka Street, Warsaw. Photo: J. Łukaszkiewicz, V 2015.

Additionally, vegetation reduces the speed of rising and falling of the sound level, which reduces the annoyance of noise [62]. According to various studies carried out in different conditions, the scope of noise reduction varies, but the share of the vegetation itself, especially high vegetation, remains unchallenged in this process. Therefore, instead of building acoustic screens in every situation, it is better to plant dense trees, which are incomparably more favorable for environmental and aesthetic reasons [63] (Figures 9 and 10).

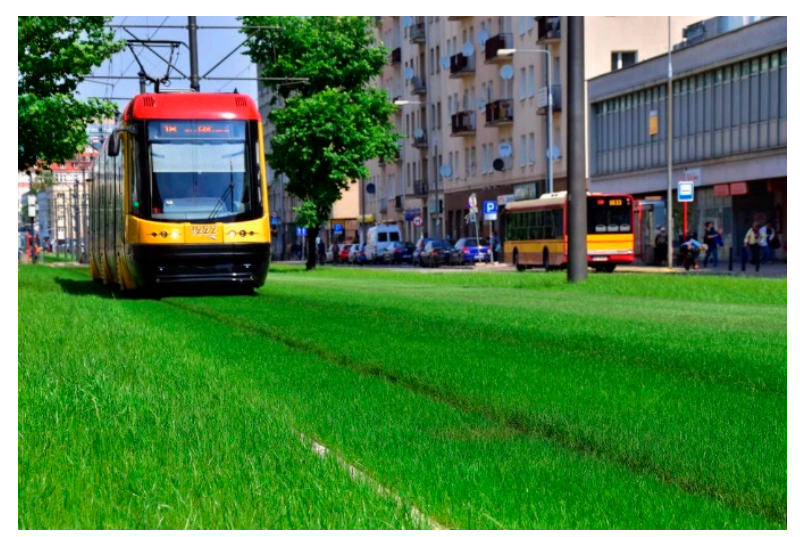

Figure 9. Single trees along the tram tracks-the remains of protective plantings from the 1960s, Warsaw, Puławska Street. Photo: Warsaw Trams, Llc., 2020 [64].

In the years 2017-2020, the authors conducted research in Warsaw, aiming to identify the condition of city tram lines in terms of their quantity (length in $\mathrm{km}$ ), their location (spatial context), and the form of the surrounding development (e.g., green or technical lanes). The obtained data show that as of 31 December 2019, the length of the single tracks reached $303.3 \mathrm{~km}(\mathrm{kmst}-\mathrm{km}$ of single tracks) (The measurement unit is 1.0 running meter of a single track (mst) or 1.0 running kilometer of a single track (kmst) [65]) including the following:

- utility tracks in depots-39.5 kmst;

- $\quad$ tracks used by passenger traffic-263.8 kmst.

Tracks applied for passenger traffic include the following: 
- $\quad$ separated tracks-211.2 kmst; including green lanes with vegetation cover-approx. $25.5 \mathrm{kmst}$;

- not separated tracks available for cars, busses, and emergency vehicles-52.6 kmst [65].

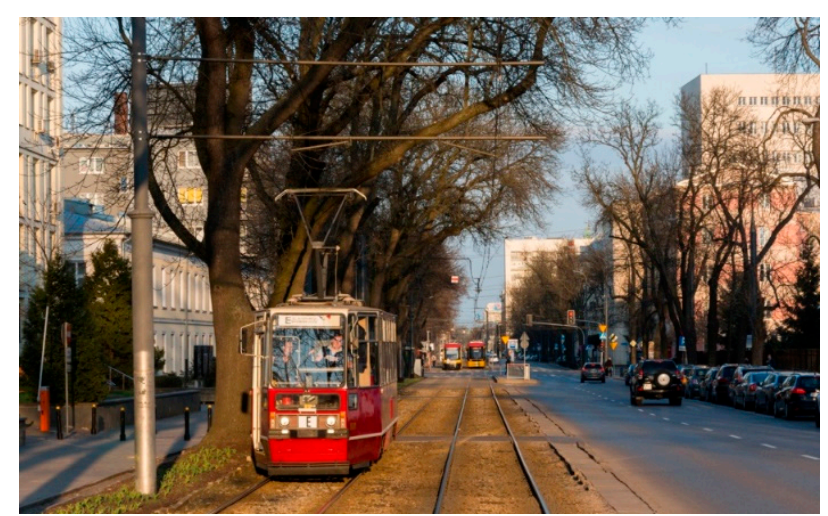

Figure 10. Trees in a row at the tram-track, Warsaw, 2019. Photo: J. Bernacki [53].

Tramlines in Warsaw connect distant districts, mainly on the north-south and eastwest axes (on both sides of the Vistula river), and they are concentrated within the city center with a high density of high-rise buildings (Figure 11).

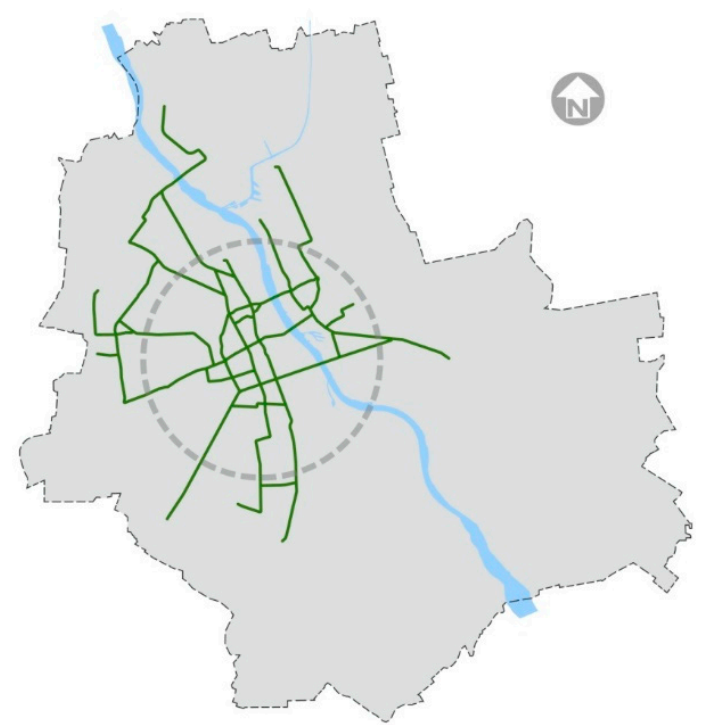

Figure 11. Diagram of the tram system in Warsaw with the central zone of the city. Compiled by P. Wiśniewski, 2021.

In recent years, the Warsaw tram lines have been modernized, including the introduction of vegetation cover (turf or herbaceous plants). Currently, such green tracks account for approx. $8.0 \%$ of the total length of all tram lines in service, and approx. $12.1 \%$ in the category of separated tracks (as specified above) applied for passenger traffic. The green tracks are covered with turf or herbaceous vegetation from genera such as Sempervivum L. or Sedum L. (Figures 12-18). 


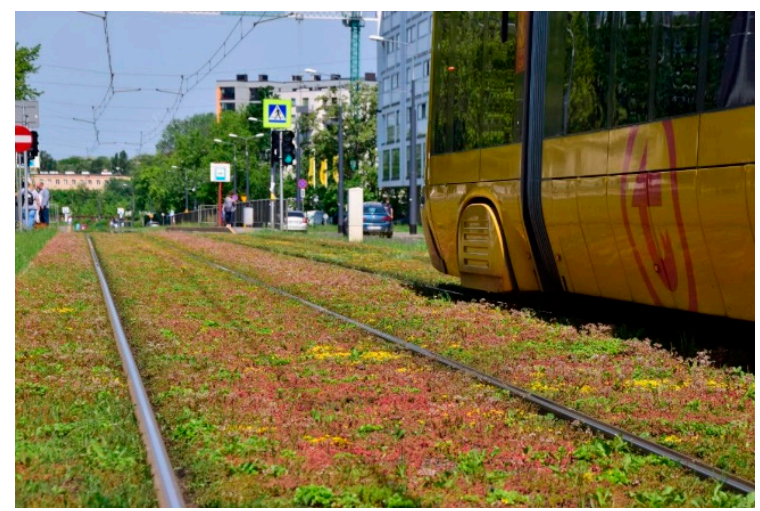

Figure 12. Warsaw: Grochowska Street, Praga district. The vegetation cover of tracks, mainly of Sempervivum L. and Sedum L. species-a very ornamental green carpet with extensive maintenance. Photo shared with permission: Warsaw Trams Llc., 2020 [65].

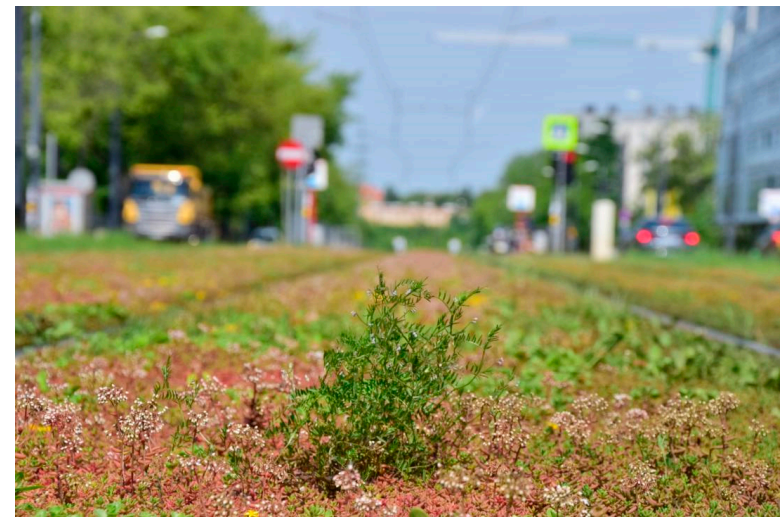

Figure 13. Warsaw: Grochowska Street, Praga district. The vegetation cover of tracks, mainly of Sempervivum L. and Sedum L. species-the Vicia cracca visible in the middle as the ruderal species indicates the beginning of seminatural plant succession. Photo shared with permission: Warsaw Trams Llc., 2020 [65].

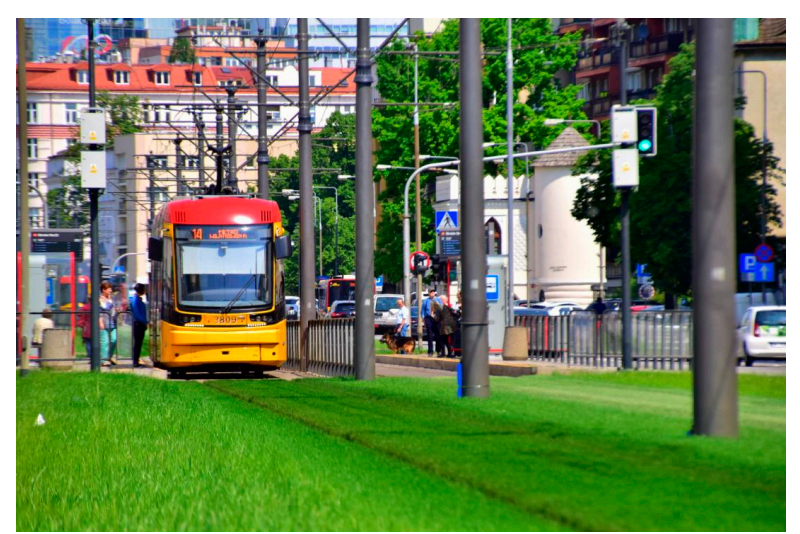

Figure 14. Warsaw: Puławska Street, Mokotów district. Smooth, grassy track cover gives a representative appearance to the main streets of the city. Photo shared with permission: Warsaw Trams Llc., 2020 [65]. 


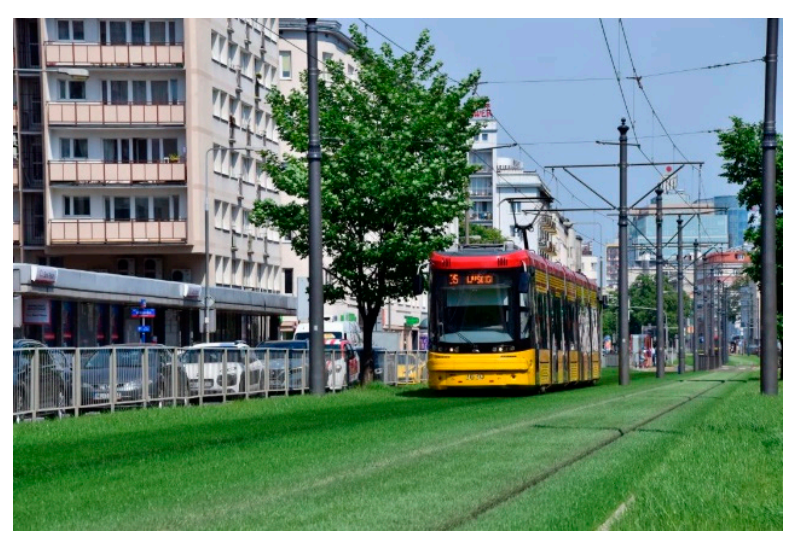

Figure 15. Warsaw: Puławska Street, Mokotów district. Smooth, grassy track cover gives a representative appearance to the main streets of the city. Photo shared with permission: Tramwaje Warszawskie Llc., 2020 [65].

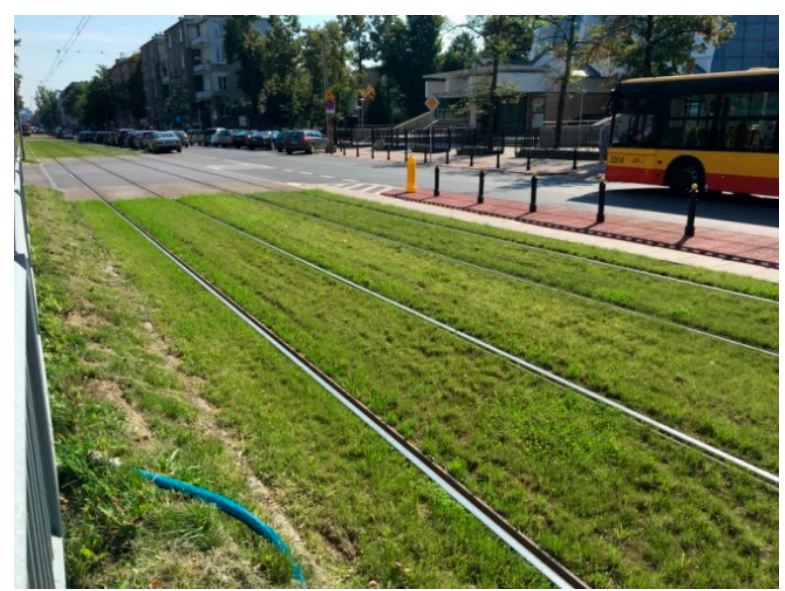

Figure 16. Warsaw: Rakowiecka Street, Mokotów district. The grassy track cover after mowing during summer. Photo: J. Łukaszkiewicz, VIII 2016 [65].

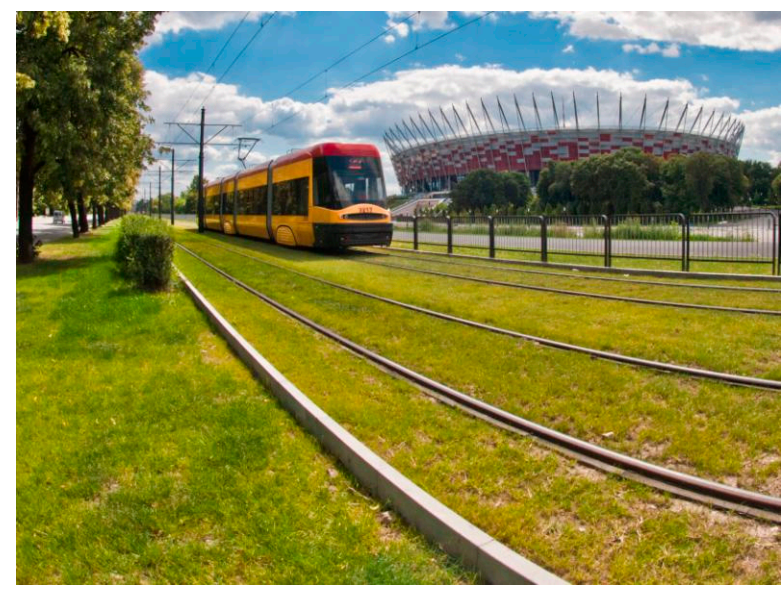

Figure 17. Warsaw: Zieleniecka Avenue, Praga district. Grassy tram lane nearby National Stadium is accomplished with a low hedge and a row of street trees on the left. Photo shared with permission: Warsaw Trams Llc., 2020 [65]. 


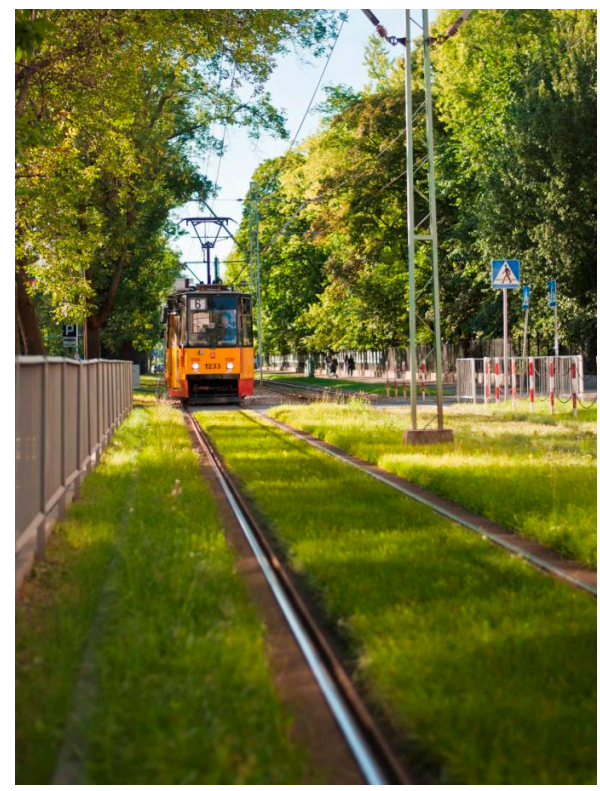

Figure 18. Warsaw: A. Mickiewicza Street, Żoliborz district. Grassy tram lane lined with rows of street trees on both sides. Photo shared with permission: Warsaw Trams Llc., 2020 [65].

The presented general data show that ca. $185.7 \mathrm{~km}$ of single tram tracks in Warsaw can be potentially transformed into a biologically active surface with turf or herbaceous vegetation cover. Some of these tracks run in separate corridors along the streets or independently across areas excluded for traffic, which offers the opportunity to introduce additional accompanying greenery (insulation and protective belts—one or double sided) of various widths.

Considering diverse spatial conditions and possible plant arrangements (different configurations of trees and shrubs connected with more or less extensive grassy areas), the authors introduced several model versions of natural protection zones (Figures 19-21). Linear vegetation belts make it possible to create insulation barriers of various densities of trees and shrubs, and in the broadest version - even to create structures like linear parks, available for direct use (added recreational function).

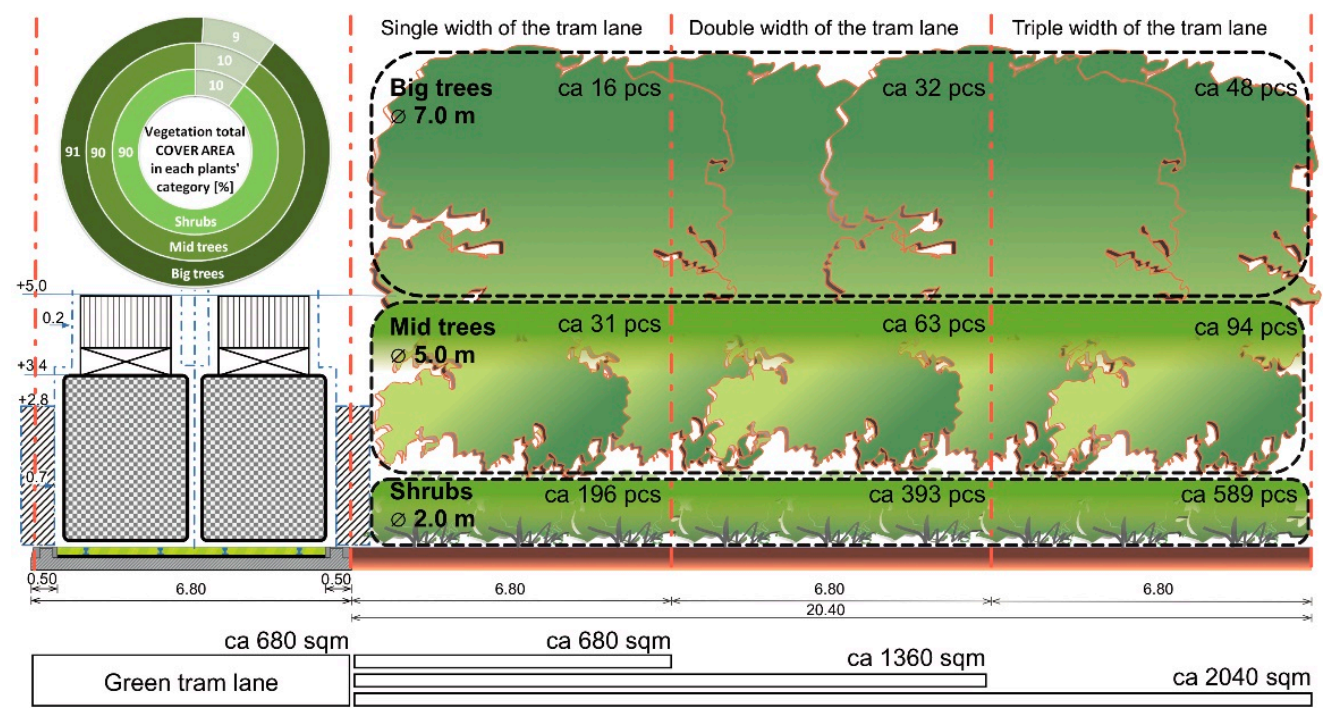

Figure 19. Model—Version 1: Land development along the tram route (one-sided intake)—a compact insulating green belt (regular triangular spacing, approx. $90 \%$ of the land area coverage). On the left: green tram route cross-section with dimensions-the pictogram after [66]. Compiled by J. Łukaszkiewicz. 


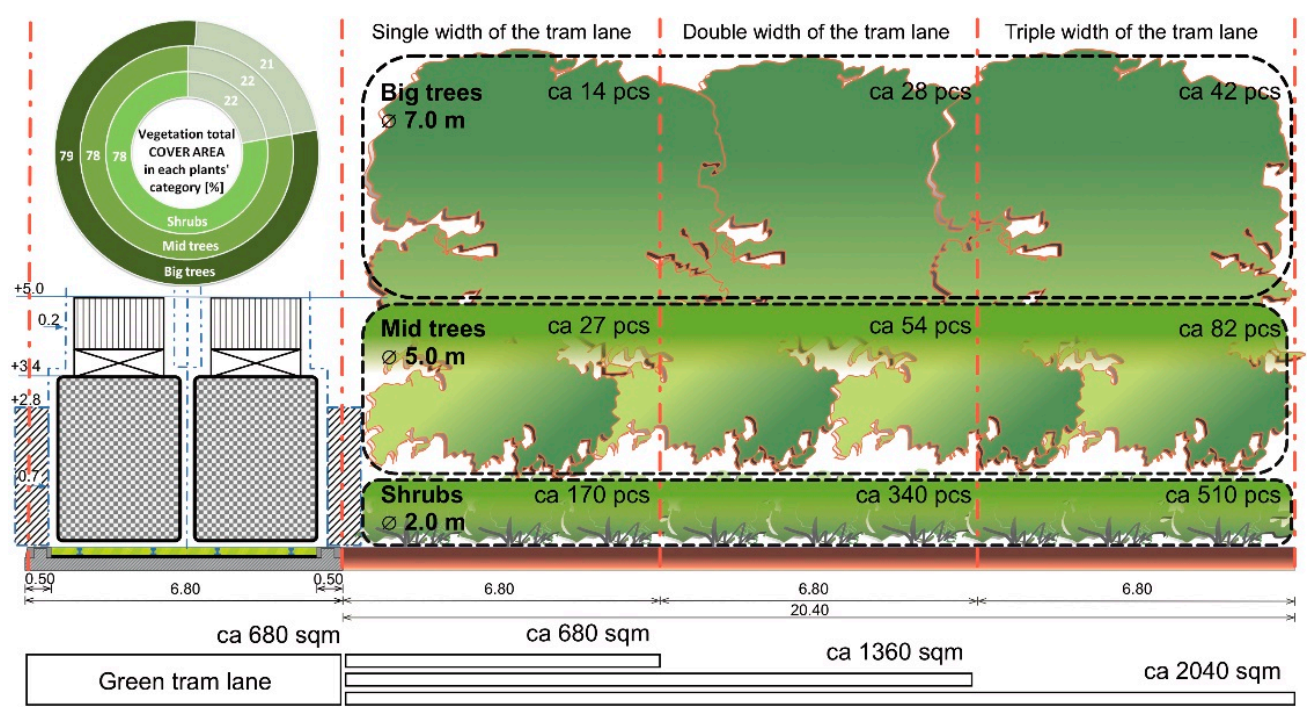

Figure 20. Model—Version 2: Land development along the tram route (one-sided intake)—a medium-dense insulating green belt (regular triangular spacing, approx. 80\% of the land area coverage). On the left: green tram route cross-section with dimensions—-the pictogram after [66]. Compiled by J. Łukaszkiewicz.

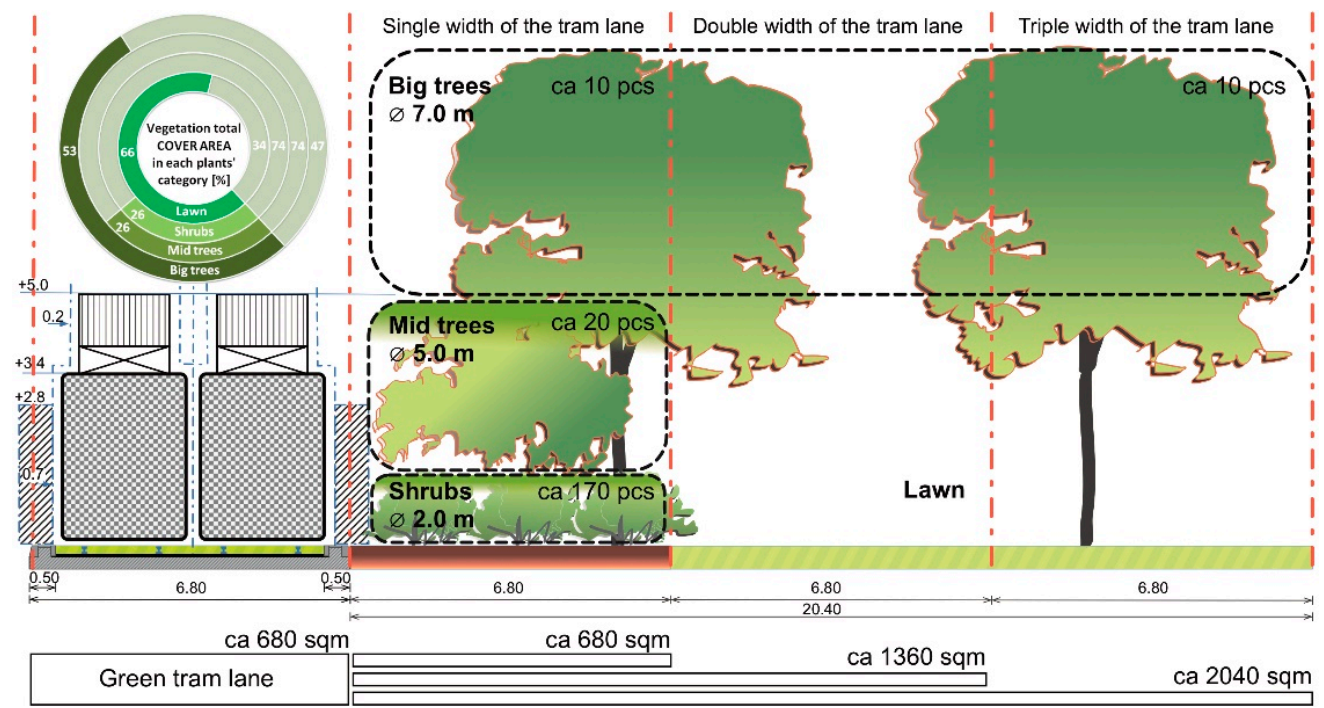

Figure 21. Model-Version 3: The linear park. Land development along the tram route with non-regular open forms of high and low greenery, providing for possible recreational use; the required width of the linear park must be at least $3 x$ Tr. On the left: green tram route cross-section with dimensions—the pictogram after [66]. Compiled by J. Łukaszkiewicz.

\subsection{The Model—Detailed Assumptions}

1. The model assumes the hypothetical development of a track section, $100.0 \mathrm{~m}$ long, with a parallel linear strip of land of the same length; the purpose of developing the model is to visualize the possibilities of enriching the surroundings of tram routes with greenery as an additional natural resource for the urban environment.

2. The conventional unit of the width applied in the model (urban unit) for the measurement of the strip of land parallel to the trackway corresponds to the basic width of the double tram track in Warsaw- $6.8 \mathrm{~m}$ (track without additional space for electric poles); the strip of land along the track may have a width of several times the width of the track; hence an additional strip of land with a width equal to a width of tracks lane (ca. $6.8 \mathrm{~m}$ ) has a total area of ca. $680 \mathrm{~m}^{2}$; a strip of land with a width equal a double width of tracks lane $($ ca. $13.6 \mathrm{~m})=$ an area of ca. $1360 \mathrm{~m}^{2}$; a strip of land with a 
width equal to 3 times the width of the double tracks lane (ca. $20.4 \mathrm{~m}$ ) = an area of ca. $2040.0 \mathrm{~m}^{2}$

3. The model presents versions of vegetation cover for a strip of land with a total width equal to three times the track's width, i.e., ca. $20.0 \mathrm{~m}$; research shows that the insulation green belts of this width are the most effective in stopping volatile and solid air pollutants, and at the same time, this width is sufficient to introduce local urban linear parks.

4. The model presents three versions of land development on one side of the tram double-track lane, assuming that the same development may occur on both sides or in a mosaic pattern.

5. It is assumed that the tram track itself has a green cover, i.e., grassy or herbaceous vegetation; the use of large trees (height $>10.0 \mathrm{~m}, \varnothing 7.0 \mathrm{~m}$ ), smaller trees (height $<10.0 \mathrm{~m}$, $\varnothing 5.0 \mathrm{~m})$, large shrubs (Ø $2.0 \mathrm{~m})$, and lawns is assumed.

\subsection{Model-Various Solutions}

Version 1. Development of the area along the tram route in the form of a green barriera compact insulating green belt (regular triangular spacing, approx. $90 \%$ of the land area coverage); estimated numbers of plants in individual categories were calculated (large trees, $\mathrm{h}>10.0 \mathrm{~m} /$ crown $\varnothing$ approx. $7.0 \mathrm{~m}$; smaller trees $\mathrm{h}<10.0 \mathrm{~m} /$ crown $\varnothing$ approx. $5.0 \mathrm{~m}$; large shrubs $\varnothing$ approx. $2.0 \mathrm{~m}$ ) for a strip of land with a length of $100.0 \mathrm{~m}$.

The width of the insulating green belt is a multiplication of the green double track width $(\mathrm{Tr}=6.8 \mathrm{~m})$; in the adopted version, the maximum width reaches the triple width of tracks lane exceeding $20.0 \mathrm{~m}$ and may be increased as far as possible and necessary, in accordance with the principle presented in the model (Figure 19).

Version 2. Development of the area along the tram route in the form of a green barriera medium-dense insulating green belt (regular square spacing, approx. $80 \%$ of the land area coverage); estimated numbers of plants in individual categories were calculated (large trees, $\mathrm{h}>10.0 \mathrm{~m} /$ crown $\varnothing$ approx. $7.0 \mathrm{~m}$; smaller trees $\mathrm{h}<10.0 \mathrm{~m} /$ crown $\varnothing$ approx. $5.0 \mathrm{~m}$; large shrubs $\varnothing$ approx. $2.0 \mathrm{~m}$ ) for a strip of land with a length of $100.0 \mathrm{~m}$.

The width of the insulating green belt is a multiplication of the green double track width $(\operatorname{Tr}=6.8 \mathrm{~m})$; in the adopted version, the maximum width reaches the triple width of tracks lane exceeding $20.0 \mathrm{~m}$ and may be increased as far as possible and necessary, in accordance with the principle presented in the model (Figure 20).

Version 3. The linear park-land development along the tram route with non-regular open forms of high and low greenery, providing high luminosity beneath the canopy, with a significant share of open grassy areas providing for possible recreational use (an implementation of path layout, equipment, etc.); on the edge of the green tram lane, the greenery of the diverse height creates a compact, insulating physical and optical green barrier. Estimated numbers of plants in individual categories (large trees, $h>10.0 \mathrm{~m} /$ crown $\varnothing$ approx. $7.0 \mathrm{~m}$; smaller trees $\mathrm{h}<10.0 \mathrm{~m} /$ crown $\varnothing$ approx. $5.0 \mathrm{~m}$; large shrubs $\varnothing$ approx. $2.0 \mathrm{~m}$ ) were determined for a strip of land with a length of $100.0 \mathrm{~m}$. The width of the green belt arranged as a linear park is a multiple of the width of the green tram lane $(\mathrm{Tr}=6.8 \mathrm{~m})$; ... in the adopted version, the maximum width reaches the triple width of tracks lane exceeding $20.0 \mathrm{~m}$ (Figure 21).

Currently, green tram lanes in Warsaw provide approx. 8.9 ha of biologically active area (a total length of approx. $25.5 \mathrm{~km}$ of a single track with the mean track width of approx. $3.5 \mathrm{~m}$ ), which is only approx. $1.78 \%$ of the total area of the ten largest parks in Warsaw (Table 2).

There is still approx. a total length of $185.7 \mathrm{kmst}$ (single tram tracks) in Warsaw potentially suitable for transformation into green lanes. If at least some of these resources are available for direct use (after excluding "technical" sections, i.e., intersections, viaducts, stops, pedestrian crossings, etc.), the following can be assumed:

- the introduction of low vegetation cover (lawns or herbaceous plants) using only $50 \%$ of the resources of available single track length (approx. $92.85 \mathrm{~km}$ ) with the 
mean-narrow version of track spacing (width of approx. $3.5 \mathrm{~m}$ ) allows obtaining approx. 32.5 ha of biologically active area in total; connecting it with the area of already existing green tracks allows 41.4 ha of biologically active area to be obtained in the scale of the entire city's tramway system;

- the possibility of introducing additional protection green belts along the tram lanes using only $20 \%$ of available $185.7 \mathrm{kmst}$ of single track length (due to restrictions resulting from spatial or technical conditions), gives approx. $37.14 \mathrm{~km}$ length of tracks in total; green belts of such a length and approx. $6.8 \mathrm{~m}$ average width would allow an additional biologically active area of approx. 25.26 ha or approx. 50.14 ha to be achieved-with green belts along tram lanes of approx. $13.5 \mathrm{~m}$ average width;

- $\quad$ the possibility of establishing a linear park in areas $20.0 \mathrm{~m}$ wide along the tram tracks would give an additional 2.0 ha of biologically active area for a $1.0 \mathrm{~km}$ long belt of greenery.

Table 2. The area of the 10 largest parks in Warsaw.

\begin{tabular}{ccc}
\hline No. & Parks of Warsaw (10 Largest) & Area (ha) \\
\hline 1 & Natolin & 105.00 \\
2 & Pole Mokotowskie & 100.00 \\
3 & Łazienki Królewskie & 76.00 \\
4 & Skaryszewski & 58.00 \\
5 & Marszałka E. Rydza-Śmigłego & 53.00 \\
6 & Bródnowski & 25.40 \\
7 & Wilanów & 24.00 \\
8 & Dolinka Służewiecka & 23.00 \\
9 & Moczydło & 19.94 \\
10 & Morskie Oko-Promenada & 17.90 \\
\hline
\end{tabular}

In general, it can be assumed that the introduction of green tram lanes, including additional local green protection zones, would allow us to realistically obtain an additional biologically active area in the city, with a minimum size of approx. from 32.5 to 57.76 ha and even 82.64 ha-potentially enlarged by at least another 2.0 ha of "tram" linear parks. These numbers in total correspond to the average area of at least one large city park (from the group of largest in Warsaw) and an increase of ca. $6.5-16.5 \%$ in the combined area of all the largest parks in Warsaw. It is difficult to imagine introducing such a significant natural area into the dense and compact structure of the city in any other way.

Finally, the great importance of social participation in the design of green areas should be emphasized, especially linear parks in the vicinity of tram routes [10]. The authors' experiences in this area show that the recreational program of the planned park facility along the tram route should depend on public consultations. Residents of separate districts may have different preferences in terms of spending free time and using such places. The linear structure of the tram route crossing various parts of the city requires that the residents of these locations be able to comment on the recreational program. For example, this type of public consultation in Warsaw was carried out in the process of preparing an investment project-the construction of a new tram route: Saska Kepa-Gocław [10] (Figure 22).

Public consultations in Poland are anchored in the currently applicable legal provisions (the Environmental Protection Act), in relation to the Directive of the European Parliament and the Council of Europe (2011/92/EU). In the discussed case, the study group consisted of participants in consultation meetings-mainly the inhabitants of Gocław and Saska Kepa. In total, about 200 people participated in all four meetings (November-December 2017). It should be emphasized that over $1 / 3$ of the participants $(35.6 \%)$ called for the implementation of the widest developed strip of land, i.e., $60.0 \mathrm{~m}$ (Figure 23), because it allowed for the creation of new publicly accessible green areas. A deficit of places for sports such as running, rollerblading, and cycling was indicated. In general, the very assumption and approach to the problem of designing a tram route in a comprehensive 
manner, taking into account the natural, landscape, and spatial context, was accepted and positively assessed by the majority of the consultation participants. Ultimately, thanks to the social dialogue, the version of the linear park next to the tram route will provide a green isolation zone of the track up to a width of $28.0 \mathrm{~m}$ and balance the interests and needs of various social groups interested in the investment (see Figure 21; model-Version 3: the linear park).

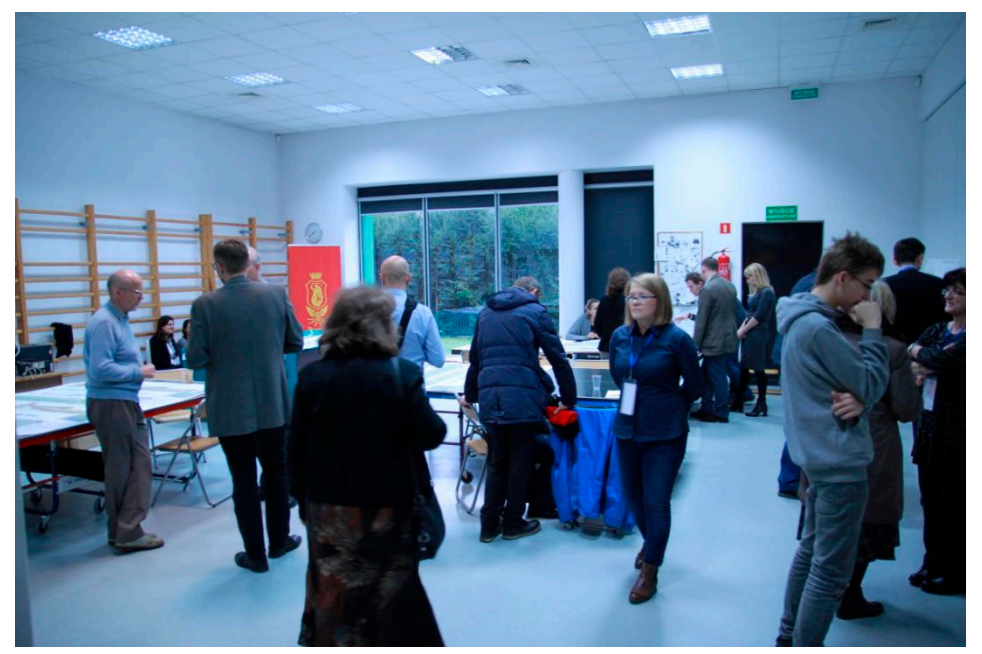

Figure 22. Public consultations regarding the development of the surroundings of the new Saska Kepa-Gocław tram route in Warsaw, conducted in the form of open consultation points, where a wide team of specialists and moderators are at the disposal of interested people on selected days.
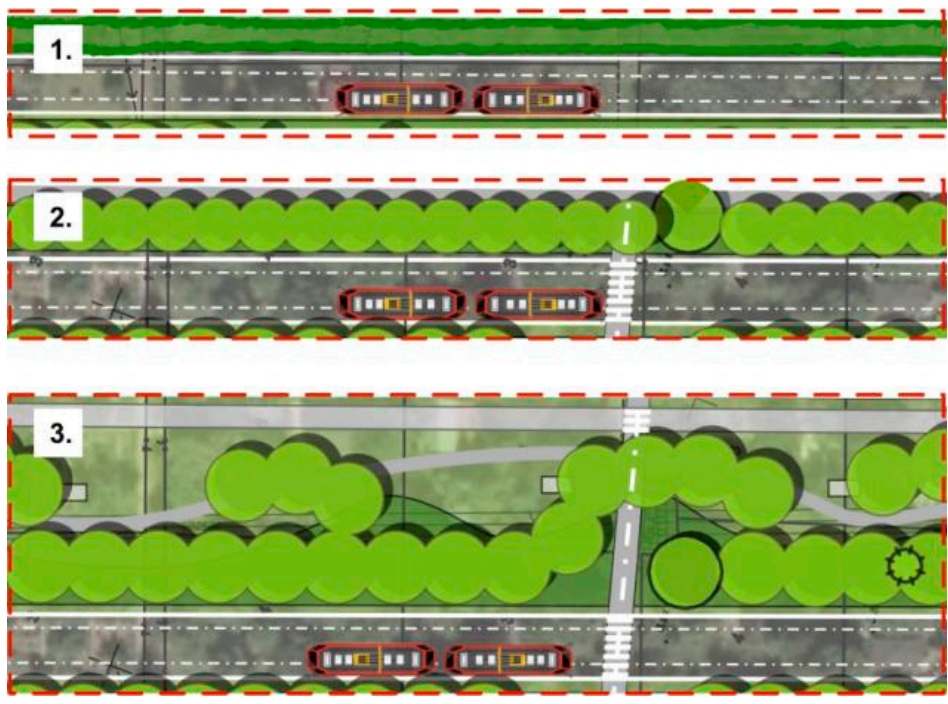

Figure 23. Insulating greenery along the planned Saska Kępa-Gocław tram route in Warsaw (three versions for public consultation). No 1. One-sided barrier of low and medium greenery (e.g., a strip of shrubs) along the tram route-with a width smaller than the width of the track itself-a frequent situation in densely built-up urban space. No 2. One-sided barrier of medium and high greenery (a belt of shrubs and trees), imitating the version of the 1st or 2nd model thanks to an additional green belt equal to one track width (the single width of tram lane). No 3. One-sided barrier of medium and high greenery - the green belt accompanying the tram reaches min. three times the width of the track (the triple width of tram lane), thanks to which it is possible to arrange greenery in a park style-linear layout—and to introduce a recreational program (roads, equipment, etc.). Graphics by J. Botwina. Compiled by J. Łukaszkiewicz [10]. 


\section{Discussion}

Warsaw, the capital of Poland, is a rapidly growing urban organism badly needing a general concept to organize this development to avoid city congestion and suffocation in the near future. One of the ideas seems to be the careful planning of the urban space growth along the tram lines as backbones of this development. The authors think that in light of the city's traumatic past and subsequent rapid development, President Starzyński's plan of building a radial structure has been lost, and now it is time to bring forward suitable plans before it is too late. Fortunately, there are examples to be followed, which are discussed here.

Sustainable development of the urban organisms involves the reduction of consumption of non-renewable spatial resources, assuming the reuse of wastelands or brownfields (e.g., [12,19-21]). Tram lines are often a perfect tool to integrate urban space, creating linear systems ("urban corridors"). In fact, the concept of development based on linear structures is not new in urban planning. The example is the idea of a linear city ("La Ciudad Lineal", ca. 1885) by the Spanish urbanist Arturo Soria y Mata (1844-1920) or the idea of "La Ville Radieuse" ("The Radiant City", 1920s) by Le Corbusier (1887-1965). Both theories later found further followers (e.g., [9,39]). For example, the concept of a "linear city" was applied in Curitiba (Curitiba), Brazil (approx. 3.0 million inhabitants) or in Australian cities (e.g., Melbourne, Coburg, and Sydney), where the tram is often an essential element of "urban corridors" $[2,5]$.

Many examples from around the world indicate that a tramway can contribute to the improvement of the visual quality of urban public space and the promotion of the image of the city itself. For example, tram lines in France (France now has 240 city tram networks) are a symbol of modernity and an expression of French cities' pro-ecological aspirations: restoring the lost public spaces, rationalizing access to public transport, and limiting the traffic (e.g., Montpellier, Strasbourg or Bordeaux and many others) [1-5].

Similar to France, the promotion of many English cities is based on the local tram system, which is used to give the city center a new identity (e.g., Sheffield, Manchester, or Nottingham). In Germany, trams are also a tool for promoting a new public image of cities, accessibility, and good quality of city life (e.g., Heilbronn, Zwickau, Bad Wildbad, and others). In Oslo (Norway), the tram, which is part of the public transport, is promoted for its functionality - as a well-developed integrated system ensuring better city connections. In the Italian region of Calabria a modern tram line connecting the metropolis of CosenzaRende and the University of Calabria has been implemented since the 1980s [1,6,9].

The most interesting solutions involving trams in the urban spaces include the revitalization of the riverside area of Abandoibarra in Bilbao (Spain). The "Bilbao Effect" means a transformation of a mining and industrial port into a center of culture, art, and entertainment [67]. Similarly, a city-wide redevelopment of infrastructure was implemented in Petržalka district (Bratislava, Slovakia). Due to the introduction of a tram-train line running through the core of the district, the integration of the existing green spaces into a defined urban green system was achieved [68].

In the Czech Republic, the Prague municipality has approved an increase in the number of green tram lanes, applying mainly local, native species of drought-resistant plants, extensive drought-loving grasses, etc. [69-72]. The vegetation-modified tram lanes in Brno serve as additional urban greenery. Such green areas are often covered with herbaceous communities, transitioning between perennial beds and landscaped lawns [73].

It should be noted that in many cases, significant sections of tram routes run fully autonomously from the traffic zones (street, roads, etc.), combining fragmented parts of urban greenery, such as in Bordeaux or Strasbourg (France), Saarbrücken or Wolfartsweier Nord (Germany), Sheffield (England), Bratislava (Slovakia), and Bilbao (Spain). In practice, greenery appears in connection with tram tracks most often for two different reasons, which may partially complement each other. The first is the need to introduce insulating greenery to act as a barrier/cover instead of a classic fence, where the tracks are separated from other road users and pedestrians by linear shrub plantings, or where medium and high 
green plantings separate the entire length of the tracks from the traffic zone (e.g., Zwickau, Wolfartsweier, or Freiburg im Breisgau-Germany) (Figure 24). The second reason is the integration of the tram routes with the urban greenery system (existing and newly developed) thanks to coherent city-wide landscape strategies (e.g., Strasbourg, Bordeaux, and Montpellier-France, or Heilbronn-Germany) [1-3,12,20,21,67,68].

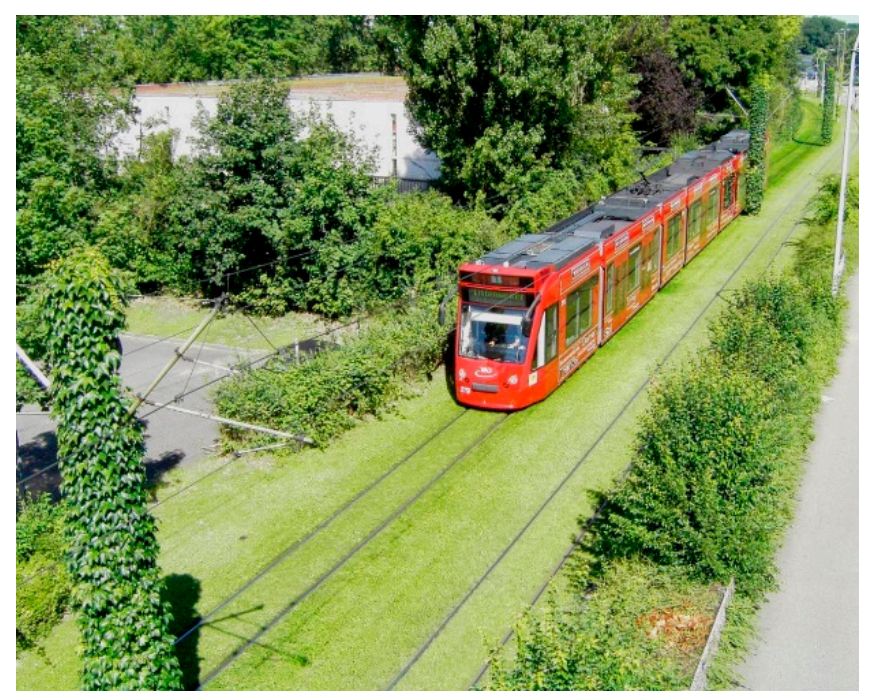

Figure 24. The tram train traveling in the "green corridor" consisting of grassy tracks, bordering trees, shrubs, and climbers attached to electric poles. Freiburg im Breisgau (Germany) has implemented numerous green tracks since 1980 [74].

Due to their often favorable location in the compact urban structure, tram lanes are predisposed to be transformed into green areas of phytoremediation, climatic, and biocenotic importance (e.g., [1-6,9,61,67-73,75]). For example, in Strasbourg, the skillfully shaped and maintained coherent continuity of green communication lanes outside the city center has resulted in biodiversity corridors-migration routes for small animals and plant seeds $[1,3]$.

The vegetation along tram lanes is very welcome to mitigate the city's climate, e.g., the level of air pollution, the effects of climate change, etc. [23,28,61,75-79]. Naturally, the ability of plants to absorb pollutants and clean the air (phytoremediation) depends on their size and vitality-trees play the most significant role in this process. In general, research shows that the appropriate structure and the maintenance of tall greenery-both its arrangement (forms, spatial arrangements) and internal structure-are of greater importance for air quality improvement. The highest efficiency in the accumulation of dust particles is achieved by isolating tall greenery forms located 3.0-15.0 m from the source of transport emissions. It is relatively more than 2.5 times more than in the case of similar tree stands, but still growing further (e.g., [28-30,34,79,80]). Air purification of dust (PM) is optimal with a sufficiently loose tree crown structure (40\% of density), reaching the optimal canopy density of approx. $35-70 \%$. By increasing size or tree density of the smallest urban green spaces (e.g., around tram lanes), a real and most noticeable effect can be achieved in cleaning up the urban atmosphere (e.g., [28-30,33-35,80,81]).

In Warsaw, the prospective opportunity for the rapid development of the tram network system is essential and dictated by the economy rules as the environmental burden is smaller than in the case of the underground (no need to make deep excavations, deal with their negative effects on the hydro-groundwork conditions, use enormous amounts of building materials, transport masses of earth - an effect of earthmoving, disorganized public transport, closed streets, construction sites, boreholes, etc.).

Increasing the biologically active area in the center zone of Warsaw is now a necessary requirement. Although greenery is introduced in every possible way (green roofs, green 
walls, greenery on terraces, etc.), the main disadvantage of these forms of vegetation is their limited or complete lack of access to all users of urban public spaces. Such persons become only passive viewers (often only from a considerable distance) of such isolated arrangements. In terms of environmental advantages, forms such as green roofs, green walls, greenery on terraces, etc., undoubtedly play an important role-they serve to increase the biologically active surface and help to reduce the urban "heat island" phenomenon; however, in terms of social values - apart from a positive aesthetic effect-they do not have a more significant impact.

The greenery which is in Warsaw associated with tram lanes is also, to some extent, excluded from direct use (especially green tracks), but it is still visually closer as it is on the street level. Undoubtedly, this has a positive effect on the reception of a given space, which thus adopts a harmonious landscape appearance. In addition, the green tram lanes are real biocenotic corridors - they allow for unhindered existence and movement of small fauna (e.g., birds, insects, earthworms). Adding the technical considerations discussed earlier (protective function), it can be concluded that the vegetation accompanying tram routes is the simplest and most advantageous way of introducing greenery into the downtown area.

The model of the greenery version interrelated to tram tracks in Warsaw presented herein carries plenty of resemblance to solutions applied in other cities and countries. This is a concise conceptualization allowing for a choice of a specific greenery version in relation to the width of the lane of the accessible ground. In the widest version of the model (Version 3), the option to introduce linear parks along the tram tracks was also taken into account. In this case, the greenery is also a recreational space, besides having the isolating function. Such solutions are popular around the world [1-6,9,67-73], and this trend is also provided for in the design of the environment of tram route Saska Kepa-Gocław, in which the authors participated [10]. Furthermore, the conceptual research concerning the greenery structure accompanying the tram lines has shown great socioeconomic importance of the public consultations at the stage of the project preparation.

The presented case studies of cities show that a complex, coherent, and thoughtful approach to tramway lane design results in their successful integration with the urban surroundings $[2,3,5,9,10,67]$. The current world standard trams are environmentally friendly; they move almost noiselessly-often on surfaces covered with vegetation or in "green corridors"- without degrading visually valuable, often historic downtown areas. The tramways meet the expectations and carry out the communication tasks of modern cities, not only without generating adverse environmental effects but also positively influencing the process of shaping public spaces [1-4,39].

Moreover, one cannot forget that every-even the smallest-fragment of visible urban greenery is of great importance in relieving stress and mental disorders in city dwellers forced to stay in confinement during the global COVID-19 pandemic [13-15].

To sum up, those responsible for development of the future shape of a city and its public transport should take a leaf out of the book on other European cities, written by the decentralization and competition between cities across Europe and all over the world, showing that the evolution of urban theories makes it necessary to combine public transport with a high-standard multifunctional urban space. The tram system is a core of such projects, implementing not only communication functions without adverse effects on the environment (compared to other means of public transport), but also positively influencing the process of shaping urban public spaces by using "green thinking" as a key factor $[1-3,5]$.

\section{Conclusions}

Trams are a key part of EU public transportation. The great importance of urban tram systems for the everyday transportation of masses of people is confirmed by the EU and Polish statistics data. The ecological advantages of trams are recognized in successive EU strategies and policies related to urban development and environmental protection. Globally, trams seem to be a vital tool for the development of urban space, which allow 
arranging and consolidating structures called "urban corridors". As additional green areas can be introduced into densely urbanized space through tramlines, the real social, environmental, and functional importance of this form of transport is finally tangible. The Warsaw tram system case study (total length over $300 \mathrm{~km}$ of single tracks in service in 2019) was implemented in order to simulate the potential growth of a biologically active area connected with an increasing share of greenery around tram lanes in Warsaw.

The suggested revitalization of the existing and designing the future tram lanes as green corridors is in line with the generally accepted concept of urban green infrastructure. Therefore, the authors aim to present their views on this significant issue in a condensed fashion, within the program of the revitalization of Warsaw landscape by converting the existing tram lines, where possible, and planning new ones according to the "green point of view".

The information used as a basis to analyze the relevant situation in Warsaw came from other studies, European as well as global, presenting the development of urban tram systems. The authors' experience in designing of the tram lane surroundings in Warsaw was of key importance for the research presented, especially in terms of greenery forms - their functionality, utility, and visual quality.

The synthesis of these issues is presented as a model with several versions, applied to Warsaw itself in the first place (as it is the case study of our research); however, the model could be applicable in other cities of the world. The development of such a model aims to indicate a potential solution to a specific problem, namely the shaping of tram route surroundings, especially with high greenery used. Our findings provide fundamental and valuable, yet overlooked, guidelines for urban tram system managers, urban policymakers, and local planners. The authors do not claim that the presented model is the only and best possible solution to the principles of designing and revitalization of greenery along tram routes. Nevertheless, it seems to be a viable overall proposition with which one can create detailed solutions adapted to the conditions of the specific site.

The paper indicates that in Warsaw-similar to other capital cities-some selected areas along the tram routes can be designed and arranged as linear parks with additional recreational functions, following the prevailing world trend. The linear park is, in a way, a contemporary approach to more traditional spatial linear forms such as a boulevard or a promenade. An excellent example of such a solution is the case of a planned tram line from Saska-Kepa to Gocław district in Warsaw. Moreover, also based on this example, this publication emphasizes the great importance of public consultations in planning new tram lines.

Taking into account all the results obtained so far, the main conclusions are as follows: (1) The presented case study (Warsaw) allows one to determine to what extent the introduction of green tracks (i.e., covered with herbaceous vegetation or additionally surrounded by tall vegetation) would realistically increase the biologically active area in the scale of the entire city; (2) With the adoption of minimum area parameters, the introduction of greenery associated with tram lines allows one to generate a biologically active area equal to a size of at least one large city park; in the case of Warsaw, it is an additional several dozen hectares of greenery in the densely built-up zone; (3) This is important especially in the central area-with dense, high-rise buildings and extensive technical infrastructurewhere there is a shortage of space available for the introduction of new natural objects (parks, squares, promenades, etc.). Often, green tram tracks are the only rational way of introducing "ground-layer" vegetation into this zone; (4) The plans of city development should also consider the "green" tram lines leading to recreational areas on the outskirts, serving at the same time as "ventilation corridors"; (5) The case of Warsaw and the spatial simulations presented in this paper seem to confirm that this kind of approach, already successfully applied in many cities around the world, appears to be the best way of tackling some key environmental issues during the continuous development of Poland's capital. 
Author Contributions: Conceptualization, methodology, and formal analysis: J.Ł. and B.F.-A.; investigation and resources: J.Ł., B.F.-A., and J.F.; data selection: J.Ł. and Ł.O.; writing—original draft preparation: J.Ł.; writing-review and editing: J.Ł., B.F.-A., and J.F.; visualization: J.Ł., B.F.-A., and Ł.O.; supervision: J.Ł., B.F.-A., and J.F. All authors have read and agreed to the published version of the manuscript.

Funding: This research received no external funding.

Institutional Review Board Statement: Not applicable.

Informed Consent Statement: Not applicable.

Acknowledgments: We would like to thank Věra Kolářová for her extremely competent help in language proofreading. We would like to thank our colleague Wiśniewski for his help in preparing graphic materials. The authors would like to thank the anonymous reviewers and editors for their constructive comments and suggestions.

Conflicts of Interest: The authors declare no conflict of interest.

\section{References}

1. Burns, M. HiTrans Best Practice Guide 3. Public Transport \& Urban Design. 2005. Available online: https://www.crow.nl/ downloads/documents/13360 (accessed on 15 January 2019).

2. Adams, R.A.M. Transforming Australian Cities. For a More Financially Viable and Sustainable Future. Transportation and Urban Design. City of Melbourne. 2009. Available online: http:/ /www.transformingaustraliancities.com.au/wp-content/uploads/ Transforming-Australian-Cities-Report.pdf (accessed on 21 September 2020).

3. Konopacki-Maciuk, Z. Trams as tools of urban transformation in French cities. Tech. Trans. Archit. 2014, 10, 61-79. [CrossRef]

4. Stipcic, M. Transit System as a Project of Urbanity. Quad. Recer. Urban. 2017, 7. Available online: https://www.raco.cat/index. $\mathrm{php} / \mathrm{QRU} /$ article/view/321810 (accessed on 12 November 2020).

5. Lu, K.; Han, B.; Zhou, X. Smart urban transit systems: From integrated framework to interdisciplinary perspective. Urban Rail Transit 2018, 4, 49-67. [CrossRef]

6. Air Quality News Magazine-May 2020 by Spacehouse-Issuu. Available online: https://issuu.com/spacehouse/docs/final. _aqn._mag._issue3.may2020 (accessed on 15 February 2021).

7. UNEP (United Nations Environmental Programme) Annual Report. 2007. Available online: http://wedocs.unep.org/bitstream/ handle/20.500.11822/7647/-UNEP\%202007\%20Annual\%20Report-2008806.pdf?sequence=5\&isAllowed=y (accessed on 17 July 2018).

8. Bouton, S.; Hannon, E.; Haydamous, L.; Heid, B.; Knupfer, S.; Naucler, T.; Neuhaus, F.; Nijssen, J.T.; Ramanathan, S. An Integrated Perspective on the Future of Mobility. McKinsey Center for Business and Environment, September 2017. Available online: https:/ / www.mckinsey.com/ \{\}/media/McKinsey/Business\%20Functions/Sustainability/Our\%20Insights/Urban\% 20commercial $\% 20$ transport $\% 20$ and $\% 20$ the $\% 20$ future $\% 20 \mathrm{of} \% 20$ mobility / An-integrated-perspective-on-the-future-of-mobility. pdf (accessed on 20 January 2019).

9. Feudo, F.L.; Festa, C.D. A Tram-Train System to Connect the Urban Area of Cosenza to Its Province: A Simulation Model of Transport Demand Modal Split and a Territorial Analysis to Identify Adapted Transit Oriented Development Prospects. In Proceedings of the Building the Urban Future and Transit Oriented Development (BUFTOD), Champs-sur-Marne, France, 17 April 2012 ; HAL Id: Hal-00734634. Available online: https:/ / hal.archives-ouvertes.fr/hal-00734634 (accessed on 4 November 2020).

10. Łukaszkiewicz, J.; Fortuna-Antoszkiewicz, B.; Botwina, J.; Oleszczuk, Ł.; Wiśniewski, P. Sustainable development of the city's transport infrastructure-A project of a new tram line with a linear park along the Exhibition Channel in Warsaw. J. Environ. Sci. Eng. A 2018, 7, 285-300. [CrossRef]

11. Jakimavičius, M.; Burinskienè, M. Multiple criteria assessment of a new tram line development scenario in Vilnius City public transport system. Transport 2013, 28, 431-437. [CrossRef]

12. Sas-Bojarska, A. Linear revitalization-Problems and challenges. Discursive article. Urban Dev. Issues 2017, 53, 5-19. [CrossRef]

13. Frumkin, H. Urban sprawl and public health. Public Health Rep. 2002, 117, 201-217. [CrossRef]

14. Ewing, R.; Meakins, G.; Hamidi, S.; Nelson, A.C. Relationship between urban sprawl and physical activity, obesity, and morbidity-Update and refinement. Health Place 2014, 26, 118-126. [CrossRef] [PubMed]

15. Soga, M.; Evans, M.J.; Tsuchiya, K.; Fukano, Y. A room with a green view: The importance of nearby nature for mental health during the COVID-19 pandemic. Ecol. Appl. 2020, 31, e02248. [CrossRef] [PubMed]

16. Althoff, J. The European Green Deal and the Future of Mobility. Available online: https://eu.boell.org/en/2020/07/20/europeangreen-deal-and-future-mobility (accessed on 20 March 2021).

17. Lynch, K. The Image of the City; MIT Press: Cambridge, MA, USA, 1960.

18. Mumford, L. The City in History-Its Origins, Its Transformations, and Its Prospects; Harcourt Brace \& World: New York, NY, USA, 1961.

19. Gehl, J. Cities for People; Island Press: Washington, DC, USA, 2010. 
20. Pluta, K. Przestrzenie Publiczne Miast Europejskich Projektowanie Urbanistyczne [Public Spaces of European Urban Designs]; Oficyna Wydawnicza Politechniki Warszawskiej: Warsaw, Poland, 2014.

21. Nyka, L. Architectural Research Addressing Societal Challenges. In From Structures to Landscapes-Towards Re-Conceptualization of the Urban Condition; Rodrigues, M.J., da Costa, C., Roseta, F., Lages, J.P., da Costa, S.C., Eds.; Taylor \& Francis Group: London, UK, 2017; pp. 509-515.

22. Feliciantonio, D.; Salvati, L.; Sarantakou, E.; Rontos, K. Class diversification, economic growth and urban sprawl: Evidences from a pre-crisis European city. Qual. Quant. 2018, 52, 1501-1522. [CrossRef]

23. UNEP/GRID-Warsaw Centre. Innovative Eco-City Conference 2018. COP24; UNEP/GRID-Warsaw Centre: Katowice, Poland, 2018; pp. 1-16. Available online: https://www.gridw.pl/innowacyjneecomiasto18?lang=en (accessed on 14 December 2020).

24. Johnson, M.P. Environmental impacts of urban sprawl: A survey of the literature and proposed research agenda. Environ. Plan. A Econ. Space 2001, 33, 717-735. [CrossRef]

25. EUdebates Team. Which European Capital Has the Best Tram System? 2020. Available online: https://eudebates.tv/debates/eupolicies/transport-and-travel/which-european-capital-has-the-best-tram-system/ (accessed on 20 March 2021).

26. City Logistics. Air Quality in Europe Is Improving. 24 November 2020. Available online: http:/ /www.citylogistics.info/research/ air-quality-in-europe-is-improving/ (accessed on 20 March 2021).

27. Smith Kevin. UITP: EU's Green Deal Must Embrace Public Transport. 28 November 2019. Available online: https://www. railjournal.com/regions/europe/uitp-green-deal-embrace-public-transport/ (accessed on 20 March 2021).

28. Popek, R.; Gawrońska, H.; Gawroński, S.W. The level of particulate matter on foliage depends on the distance from the source of emission. Int. J. Phytoremediat. 2015, 17, 1262-1268. [CrossRef]

29. Gawroński, S.W. Fitoremediacyjna Rola Roślin na Terenach Zurbanizowanych (Phytoremediation Role of Plants in Urbanized Areas); Nowak, G., Kubus, M., Sobisz, Z., Eds.; Drzewa i Krzewy w Rekultywacji (Trees and Shrubs in Environmental Reclamation), Mat. IX Zjazdu Polskiego Towarzystwa Dendrologicznego. Konferencja Naukowa, Wirty-Ustka, 19-22 września 2018 r. Wyd; Polskie Towarzystwo Dendrologiczne: Szczecin, Poland, 2018; pp. 19-27.

30. Sgrigna, G.; Sæbø, A.; Gawronski, S.; Popek, R.; Calfapietra, C. Particulate Matter deposition on Quercus ilex leaves in an industrial city of central Italy. Environ. Pollut. 2015, 197, 187-194. [CrossRef]

31. Moreno, T.; Reche, C.; Rivas, I.; Minguill'on, M.C.; Martins, V.; Vargas, C.; Buonanno, G.; Parga, J.; Pandolfi, M.; Brines, M.; et al. Urban air quality comparison for bus, tram, subway and pedestrian commutes in Barcelona. Environ. Res. 2015, 142, 495-510. [CrossRef]

32. Canales, D.; Bouton, S.; Trimble, E.; Thayne, J.; Da Silva, L.; Shastry, S.; Knupfer, S.; Powell, M. Connected Urban Growth: PublicPrivate Collaborations for Transforming Urban Mobility; Coalition for Urban Transitions: London, UK; Washington, DC, USA, 2017; Available online: http:/ / newclimateeconomy.net/content/cities-working-papers (accessed on 15 October 2018).

33. Matos, P.; Vieira, J.; Rocha, B.; Branquinho, C.; Pinho, P. Modeling the provision of air-quality regulation ecosystem service provided by urban green spaces using lichens as ecological indicators. Sci. Total Environ. 2019, 665, 521-530. [CrossRef] [PubMed]

34. Jin, S.; Guo, J.; Wheeler, S.; Kan, L.; Che, S. Evaluation of impacts of trees on PM2.5 dispersion in urban streets. Atmos. Environ. 2014, 99, 277-287. [CrossRef]

35. Yang, J.; Chang, Y.; Yan, P. Ranking the suitability of common urban tree species for controlling PM2.5 pollution. Atmos. Pollut. Res. 2015, 6, 267-277. [CrossRef]

36. Reksins, M. (Ed.) Strategy for the sustainable development of the Warsaw transport system until 2015 and for the following years. In Resolution No. LVIII/1749/2009 of the City Council of Warsaw of 9 July 2009; City Council of Warsaw: Warsaw, Poland. (In Polish)

37. Nyka, L. Przestrzeń Miejska Jako Krajobraz [Urban Space as Landscape]; Czasopismo Techniczne 1-A; Architektura: Krakow, Poland, 2012; pp. 49-59.

38. Smart City Blog. Kolejne Środki Z Ue Na Transport Publiczny W Miastach [More Eu Funds for Public Transport in Cities]. Available online: https:/ / smartcityblog.pl/transport-publiczny-w-miastach/ (accessed on 20 November 2020). (In Polish).

39. Furundzic, D.S.; Furundzic, B.S. Infrastructure Corridor as Linear City. In Proceedings of the 1st International Conference on Architecture \& Urban Design, Epoka Unversity, Triana, Albania, 19-21 April 2012; pp. 721-728. Available online: https: / / core.ac.uk/download/pdf/152488845.pdf (accessed on 19 December 2020).

40. RailwayPro. Public Transport is a Must under the EU's Green Deal. 29 November 2019. Available online: https://www. railwaypro.com/wp/public-transport-is-a-must-under-the-eus-green-deal/ (accessed on $20 \mathrm{March} 2021$ ).

41. Quing, L.; Shinrin, Y. Pengiun Life. In The Art and Science of Forest Bathing; Insignis Media: Kraków, Poland, 2018.

42. Beister, M.; Górny, J.; Połom, M. Rozwój Infrastruktury Tramwajowej w Polsce w Okresie Członkostwa w Unii Europejskiej [The of the Publisherdevelopment of the Tramway Infrastructure in Poland during Accession to the European Union]. Tech. Transp. Szyn. 2015, 22, 20-36. Available online: http:/ / www.tts.infotransport.pl/pl/ (accessed on 20 March 2021).

43. Statistics Poland. Statistical Products Department. Statistical Yearbook of the Republic of Poland 2019; Statistics Poland: Warsaw, Poland, 2019.

44. Statistics Poland. Tramways in Poland; Statistics Poland: Warsaw, Poland, 2018. Available online: https://stat.gov.pl/infografikiwidzety/infografiki/infografika-tramwaje,74,1.html (accessed on 20 March 2021).

45. Oleksiewicz, W.A. Rozwój Zielonych Torowisk Tramwajowych w Polsce (Development of Green Tram Tracks in Poland); X Konferencja Naukowo-Techniczna "Miasto i Transport 2016"; Unpublished material-presentation.

46. Warsaw Trams, L. [Tramwaje Warszawskie sp. z o.o.]. Unpublished Report 2019. (In Polish). 
47. Urbanowicz, W. Tramwaje Warszawskie Przetestują Zielone Torowisko na Tłuczniu. 2019. Available online: https://www. transport-publiczny.pl/mobile/tramwaje-warszawskie-przetestuja-zielone-torowisko-na-tluczniu-63017.html (accessed on 4 December 2020).

48. Starzyński, S. Rozwój Stolicy (Odczyt Wygłoszony w Dniu 10 Czerwca 1938 r. na Zebraniu Urzadzonym Przez Stołeczny Okręg Zwiazku Rezerwistów). [Development of the Capital (Lecture Delivered on 10 June 1938 at a Meeting Organized by the Capital District of the Union of Reservists).]; Wyd. Przez Stołeczny Okręg Związku Rezerwistów; [druk] Drukarnia Współczesna Sp. z o.o.: Warszawa, Poland, 1938. (In Polish)

49. Starzyński, S. Sprawozdanie Prezydenta m. st. Warszawy Stefana Starzyńskiego za Okres od 3 III 1934 do 23 II 1939 Wygtoszone na 50 Posiedzeniu Tymczasowej Rady Miejskiej w Dniu 23 Lutego 1939 Roku. [The Report of the President of the Capital City of Warsaw, Stefan Starzyński, for the Period from 3 March 1934 to 23 February 1939, Delivered at the 50th Session of the Provisional City Council on 23 February 1939]; Wyd. Zarząd Miejski w m. st. Warszawie; [druk] Drukarnia Miejska: Warszawa, Poland, 1939. (In Polish)

50. Fortuna-Antoszkiewicz, B. Przemiany Formy Elementów I Układów Ogrodowych Wzdłuż Traktów Komunikacyjnych Na Przykładzie Traktu Królewskiego W Warszawie [Form's Transformations of Garden Elements and Arrangements Longwise Roads on the Example of Royal Road in Warsaw]; SGGW: Warsaw, Poland, 2012.

51. Ptaszycka, A. Przestrzenie Zielone W Miastach [Green Spaces in Cities]; Ludowa Spółdzielnia Wydawnicza: Oddział w Poznaniu, Poznań, 1950.

52. Co Pamięta Warszawa. Available online: https://culture.pl/pl/artykul/co-pamieta-warszawa (accessed on 15 February 2021).

53. Klub Miłośników Komunikacji Miejskiej.Blog. 111 Lat Tramwaju Elektrycznego [111 Years of the Electric Tram] 10 April 2019. Available online: https:/ / kmkm.waw.pl/111-lat-tramwaju-elektrycznego/ (accessed on 20 November 2020). (In Polish)

54. SISCOM. Available online: http:/ / siskom.waw.pl/kp-tramwaje.htm (accessed on 20 March 2021).

55. Woźnicka, M.; Barszcz, P.; Janeczko, K.; Staniszewski, P.; Fortuna-Antoszkiewicz, B. Noise Level in Recreational Forest Management Areas on a Selected Example. In Proceedings of the Public Recreation and Landscape Protection-With nature hand in hand! Křtiny, Czech Republic, 2-4 May 2018; Fialová, J., Ed.; Wyd. Mendel University in Brno: Brno, Czechia, 2018; pp. 267-271.

56. Piechowicz, J.; Ozga, A.; Mleczko, D.; Kasprzak, C.; Stryczniewicz, L. Ekologia Akustyczna na Obszarach Leśnych [Acoustic Ecology in Forest Areas]; Wyd. Kat. Mechaniki i Wibroakustyki, Wydz. Inżynierii Mechanicznej i Robotyki, AGH im; Stanisława Staszica w Krakowie: Kraków, Poland, 2015. (In Polish)

57. Engel, Z. Ochrona Środowiska Pracy Przed Drganiami i Hałasem [Environment Protection Against Vibration and Noise]; Wydawnictwo Naukowe PWN: Warszawa, Poland, 1993. (In Polish)

58. Niemirski, W. Kształtowanie Terenów Zieleni; Arkady: Warszawa, Poland, 1973. (In Polish)

59. Sadowski, J.; Wodziński, L. Akustyka Miasta [City Acoustics]; z. 12.148: 1955; Architektura: Warsaw, Poland. (In Polish)

60. Sadowski, J. Podstawy Akustyki Urbanistycznej [Basics of Urban Acoustics]; Arkady: Warszawa, Poland, 1982. (In Polish)

61. Jakubcová, E.; Horváthová, E. Urban heat island mitigation-Microclimate regulation. Sci. Agric. Bohem. 2020, 51, 99-106.

62. Makarewicz, R. Hałas w Środowisku [Noise in the Environment]; Ośrodek Wydawnictw Naukowych: Poznań, Poland, 1996.

63. Fortuna-Antoszkiewicz, B. Roślinność W Kompozycji Przestrzennej-Wartości i Zachowanie Dziedzictwa [Vegetation in Spatial Composition-Values and Preservation of Heritage]; Wyd. SGGW: Warszawa, Poland, 2019. (In Polish)

64. Single Trees by the Tram Tracks-The Remains of Protective Plantings from the 1960s; Warsaw Trams, LLC.: Warsaw, Poland, 2020.

65. Granted Permission for Sahing Photos, 2020-2021; Warsaw Trams, LLC.: Warsaw, Poland, 2020.

66. Neufert, E. Podręcznik Projektowania Architektoniczno-Budowlanego [Architectural and Construction Design Manual]; Arkady: Warsaw, Poland, 1995.

67. Taplin, M. Bilbao: First Line is Just the Beginning. Available online: http:/ /www.lrta.org/mag/articles/art0403.html (accessed on 25 September 2018).

68. Green Urban Axis-Petržalka Masterplan, Bratislava, Slovakia. Available online: http://markoandplacemakers.com/projects/ green-urban-axis-petr-alka-masterplan-bratislava-slovakia (accessed on 15 February 2021).

69. Ozelěnění Tramvajových Pásů-TZB-Info. Available online: https://stavba.tzb-info.cz/terasy-a-zpevnene-plochy/21444ozeleneni-tramvajovych-pasu (accessed on 15 February 2021).

70. Záchranár̆ům Vadí Tráva na Kolejích. Available online: https:/ / prazsky.denik.cz/zpravy_region/zachranarum-vadi-trava-nakolejich-20160903.html (accessed on 15 February 2021).

71. Harciník, J. Povrchy Tramvajových Tratí Hlavního Města Prahy; Institut Plánování a Rozvoje hl. m: Prahy, Czech Republic, 2016 ; p. 44.

72. Zelené Tramvajové Pásy Oživí Prahu. Výzkumníci už Testují Nejvhodnější Rostliny—Pražský Deník. Available online: https: //prazsky.denik.cz/zpravy_region/zeleny-tramvajovy-pas-doprava-klima-ekologie-rostlina-chytre-mesto.html (accessed on 15 February 2021).

73. Cejpková, K. Principy Tvorby Veřejných Prostranství; Kancelář architekta města Brna: Brno, Czech Republic, 2019 ; pp. 110-150.

74. Trams in Freiburg im Breisgau. Available online: https://en.wikipedia.org/wiki/Trams_in_Freiburg_im_Breisgau (accessed on 20 March 2021).

75. Šeptunová, Z.; Rieger, V.; Kundrata, M.; Hollan, J.; Gaillyová., Y.; Sedlák, R. Adaptační Opatření na Zmírňování Vlivu Klimatickýxh Změn pro Město Brno; Nadace Partnerství: Brno, Czech Republic, 2017; p. 8. Available online: https://www.lifetreecheck.eu/ getattachment/c3688a57-a8eb-4925-ada7-47f1ef66c675/attachment\%22 (accessed on 15 February 2021).

76. McPherson, G.E. Benefit-based tree valuation. Arboric. Urban For. 2007, 33, 1-11. 
77. McPherson, G.E.; Simpson, J.R.; Scott, K.I. Actualizing microclimate and air quality benefits with parking lot tree shade ordinances. Wetter Und Leben 2001, 50, 353-369.

78. Chee Keng Lee, A.; Jordan, H.C.; Horsley, J. Value of urban green spaces in promoting healthy living and wellbeing: Prospects for planning. Risk Manag. Healthc. Policy 2015, 8, 131-137. [CrossRef]

79. Borowski, J.; Fortuna-Antoszkiewicz, B.; Łukaszkiewicz, J.; Rosłon-Szeryńska, E. Conditions for the effective development and protection of the resources of urban green infrastructure. E3S Web Conf. 2018, 45, 1-8. [CrossRef]

80. Sæbø, A.; Popek, R.; Nawrot, B.; Hanslin, H.M.; Gawrońska, H.; Gawroński, S.W. Plant species differences in particulate matter accumulation on leaf surfaces. Sci. Total Environ. 2012, 427-428, 347-354. [CrossRef]

81. Wang, X.; Teng, M.; Huang, C.; Zhou, Z.; Chen, X.; Xiang, Y. Canopy density effects on particulate matter attenuation coefficients in street canyons during summer in the Wuhan metropolitan area. Atmos. Environ. 2020, 240, 117739. [CrossRef] 